\title{
Implications of the 2011-13 Syrian Uprising for the Middle Eastern Regional Security Complex
}

Fred H. Lawson

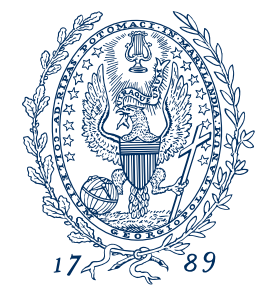

GEORGETOWN UNIVERSITY

School of Foreign Service in Qatar Center for International and Regional Studies

(C) 2014 



\section{Implications of the 2011-13 Syrian Uprising for the Middle Eastern Regional Security Complex}

Fred H. Lawson

(C) 2014 Center for International and Regional Studies

Georgetown University School of Foreign Service in Qatar

Occasional Paper No. 14

ISSN 2072-5957 


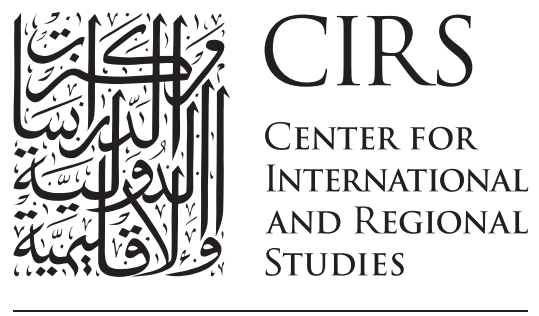

GEORGETOWN UNIVERSITY

SCHOOL OF FOREIGN SERVICE IN QATAR

Established in 2005, the Center for International and Regional Studies at the Georgetown University School of Foreign Service in Qatar is a premier research institute devoted to the academic study of regional and international issues through dialogue and exchange of ideas, research and scholarship, and engagement with national and international scholars, opinion-makers, practitioners, and activists.

Guided by the principles of academic excellence, forward vision, and community engagement, the CIRS mission revolves around five principal goals:

- To provide a forum for scholarship and research on international and regional affairs;

- To encourage in-depth examination and exchange of ideas;

- To foster thoughtful dialogue among students, scholars, and practitioners of international affairs;

- To facilitate the free flow of ideas and knowledge through publishing the products of its research, sponsoring conferences and seminars, and holding workshops designed to explore the complexities of the twentyfirst century;

- To engage in outreach activities with a wide range of local, regional, and international partners.

This publication series is made possible by the generous support of Qatar Foundation for Education, Science and Community Development. 


\section{Implications of the 2011-13 Syrian Uprising for the Middle Eastern Regional Security Complex}

Fred H. Lawson

Fred H. Lawson is Lynn T. White, Jr. Professor of Government at Mills College in Oakland, California. He is author of Global Security Watch Syria (2013), Constructing International Relations in the Arab World (2006), and editor of Comparative Regionalism (2009), and Demystifying Syria (2009). In 2009-2010, Lawson was Senior Fellow at the Center for International and Regional Studies (CIRS) at the Georgetown University School of Foreign Service in Qatar. He is past president of both the Society for Gulf Arab Studies and the Syrian Studies Association. 


\begin{abstract}
By the autumn of 2013, the Middle Eastern regional security complex (RSC) had taken on a new configuration, which was substantially different from - and much more explosive than — the one that existed prior to the large-scale popular uprisings that broke out across the Arab world in the winter of 2010-11. Foreign policies adopted between 2000 and 2010 by the Ba'thi regime in Damascus, the leaderships of Hizbullah and HAMAS, and the Israeli government to parry overlapping internal and external threats created an unprecedented patchwork of strategic rivalries and alignments. Large-scale popular unrest in Iraq and Egypt in early 2011, along with the outbreak of full-scale civil war in Syria later that same year, generated an even more intricate web of interstate security dynamics. The reconfigured RSC that emerged out of the "Winter of Arab Discontent" is only beginning to be explicated, and can best be addressed by tracing the connection between domestic political conflicts and shifts in external belligerence and alignment across the region.
\end{abstract}




\section{List of Organizations}

\begin{tabular}{|c|c|c|c|}
\hline English & Acronym & Arabic & \begin{tabular}{|l|} 
Transliteration \\
\end{tabular} \\
\hline Party of God & & حزب الله & Hizbullah \\
\hline $\begin{array}{l}\text { Palestinian Islamic Resistance } \\
\text { Movement }\end{array}$ & HAMAS & 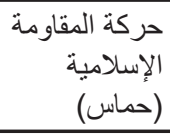 & $\begin{array}{l}\text { Harakat al- } \\
\text { Muqawamah al- } \\
\text { Islamiyyah } \\
\end{array}$ \\
\hline Free Resistance Brigade & & $\begin{aligned} \text { لواء المقاومة } \\
\end{aligned}$ & $\begin{array}{l}\text { Liwa' al-Muqawamah } \\
\text { al-Hurra }\end{array}$ \\
\hline Islamic Resistance Companies & & $\begin{aligned} \text { الإسلامية المقاومة } \\
\end{aligned}$ & $\begin{array}{l}\text { Saraya al-Muqawamah } \\
\text { al-Islamiyyah }\end{array}$ \\
\hline Liberation Party & & حزب التحرير & Hizb al-Tahrir \\
\hline al-Qa'ida in the Lands of Syria & & بلاد الثشام في & $\begin{array}{l}\text { al-Qaida fi Bilad al- } \\
\text { Sham }\end{array}$ \\
\hline Enough Movement & & حركة كفاية & Kifaya \\
\hline State of Law Coalition & & القتانلاف دولة & I'tilaf Dawlat al-Qanun \\
\hline Iraqi List & & القائمة العر اقية & $\begin{array}{l}\text { al-Qa'imah al- } \\
\text { 'Iraqiyyah } \\
\end{array}$ \\
\hline $\begin{array}{l}\text { Assistance Front for the People of the } \\
\text { Lands of Syria }\end{array}$ & & جالهل الشام النصرة & $\begin{array}{l}\text { Jabhat al-Nusrah li-Ahl } \\
\text { al-Sham }\end{array}$ \\
\hline Free of Syria & & كتائب أحرار & Kata'ib Ahrar al-Sham \\
\hline Brigade of Syria Falcons & & صقور الثنام & Suqur al-Sham \\
\hline Brigade of the Community of Believers & & لو لواء الأمة & Liwa' al-Ummah \\
\hline Dawn of Islam Movement & & الإسلامة فجر & Harakat Fajr al-Islam \\
\hline Syrian Islamic Front & & الإلجامية & $\begin{array}{l}\text { al-Jabhah al-Islamiyyah } \\
\text { al-Suriyyah }\end{array}$ \\
\hline Al-Faruq Brigade & & لو ل اء الفاروق & Liwa' al-Faruq \\
\hline Islam Brigade & & لو لواء الإسلام & Liwa' al-Islam \\
\hline Islamic Liberation Front & & الإسلامية التحرير & $\begin{array}{l}\text { Jabhat al-Tahrir al- } \\
\text { Islamiyyah }\end{array}$ \\
\hline Bands of the People of Truth & & $\begin{aligned} \text { الدقائب أهل } \\
\end{aligned}$ & 'Asa'ib Ahl al-Haqq \\
\hline Mahdi Army & & جيش المهدي & Jaish al-Mahdi \\
\hline Badr Organization & & منظمة بدر & Munazzamat Badr \\
\hline Islamic State of Iraq & ISI & الإلسلامية في & $\begin{array}{l}\text { al-Dawlah al- } \\
\text { Islamiyyah fi al-'Iraq }\end{array}$ \\
\hline
\end{tabular}




\begin{tabular}{|c|c|c|c|}
\hline English & Acronym & Arabic & Transliteration \\
\hline Islamic State of Iraq and the Levant & ISIL & 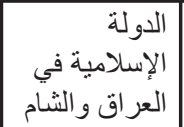 & $\begin{array}{l}\text { al-Dawlah al- } \\
\text { Islamiyyah fi al-'Iraq } \\
\text { wa al-Sham }\end{array}$ \\
\hline God is Greatest Brigade & & لو اء الله أكبر & Liwa' Allahu Akbar \\
\hline Unity Brigade & & لواء التوحيد & Liwa' al-Tawhid \\
\hline Mukhtar Army & & | جيش المختار & Jaish al-Mukhtar \\
\hline $\begin{array}{l}\text { Army of the Men of the Naqshbandi } \\
\text { Order }\end{array}$ & & النقيش رجال & $\begin{array}{l}\text { Jaish Rijal al-Tariqah } \\
\text { al-Naqshbandiyyah }\end{array}$ \\
\hline Popular Nasirist Organization & & \begin{tabular}{|r|} 
النتظيم الثعبي \\
\end{tabular} & $\begin{array}{l}\text { al-Tanzim al-Sha'bi } \\
\text { al-Nasiri }\end{array}$ \\
\hline Islamic National Gathering & & |الإسلاميع القومي & $\begin{array}{l}\text { al-Tajammu' al-Qawmi } \\
\text { al-Islami }\end{array}$ \\
\hline The Free of Tripoli & & 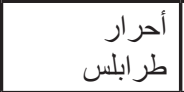 & Ahrar Tarabulus \\
\hline 'Abdullah 'Azzam Brigades & & 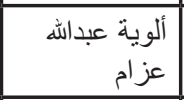 & $\begin{array}{l}\text { Alwiyat 'Abdullah } \\
\text { 'Azzam } \\
\end{array}$ \\
\hline Kurdistan Regional Government & KRG & & \\
\hline Kurdistan Workers' Party & PKK & & \\
\hline Israel Defense Force & IDF & & \\
\hline Party for a Free Life in Kurdistan & PJAK & & \\
\hline Peace and Democracy Party & BDP & & \\
\hline Kurdistan Democratic Party & KDP & & \\
\hline Patriotic Union of Kurdistan & PUK & & \\
\hline Democratic Union Party & PYD & & \\
\hline Popular Protection Units & YPG & & \\
\hline Kurdish Unity Party & Yakiti & & \\
\hline Islamic Revolutionary Guards Corps & IRGC & & \\
\hline
\end{tabular}

Note: Transliterations follow the style set by the International Journal of Middle East Studies. 


\section{Introduction}

By the autumn of 2013, the Middle Eastern regional security complex (RSC) had taken on a new configuration, which was substantially different from-and much more explosive than-the one that existed prior to the large-scale popular uprisings that broke out across the Arab world in the winter of 2010-11. This RSC expanded during the first decade of the twenty-first century to include not only the core actors of Syria, Israel, the Lebanese Shi'i movement Hizbullah (Party of God), and the Palestinian Harakat al-Muqawamah al-Islamiyyah (Islamic Resistance Movement) or HAMAS, but also Turkey, the Islamic Republic of Iran, Iraq, and Lebanon. ${ }^{1}$ Moreover, persistent Israeli efforts to cultivate new markets for its high technology exports, as well as to forge strategic partnerships that might counteract Syria's growing links to Turkey and Iraq, entangled several former Soviet republics of the South Caucasus and Central Eurasia in regional affairs. Egypt, Jordan, and the Palestinian Authority hovered uneasily on the sidelines, due to the peace treaties that they had signed with Israel in March 1979, October 1994, and September 1993, respectively.

Foreign policies adopted between 2000 and 2010 by the Bathi regime in Damascus, the leaderships of Hizbullah and HAMAS, and the Israeli government to parry overlapping internal and external threats created an unprecedented patchwork of strategic rivalries and alignments. Large-scale popular unrest in Iraq and Egypt in early 2011, along with the outbreak of full-scale civil war in Syria later that same year, generated an even more intricate web of interstate security dynamics. The reconfigured RSC that emerged out of what Gregory Gause calls the "Winter of Arab Discontent" is only beginning to be explicated, most often by scholars who draw explicit analogies to earlier moments in regional affairs.

\section{Regional Security and the New Arab Cold War}

Several observers have tried to explain the impact of the 2010-13 uprisings on the Middle Eastern RSC by resurrecting Malcolm Kerr's notion of an Arab Cold War. ${ }^{2}$ Nabeel Khoury, for instance, proposes that three kinds of regional actors have emerged in the wake of the revolts: "conservative monarchies, transitioning republics and nonstate Islamic groups." ${ }^{3}$ The transitioning republics, Khoury asserts, can be expected to

\footnotetext{
${ }^{1}$ Fred H. Lawson, "New Twists, More Intricate Configurations: The Changing Israel-Palestinian Regional Security Complex," Perspectives on Global Development and Technology 6, nos. 1-3 (2007): 345-362.

${ }^{2}$ Malcolm H. Kerr, The Arab Cold War: Gamal Abd al-Nasir and His Rivals, 1958-1970, $3^{\text {rd }}$ ed. (London: Oxford University Press, 1971).

${ }^{3}$ Nabeel A. Khoury, "The Arab Cold War Revisited: The Regional Impact of the Arab Uprising," Middle East Policy 20, no. 2 (Summer 2013): 73.
} 
be ruled by Islamist movements of one sort or another, and to be actively supported by Turkey and tolerated by the richer Arab states of the Persian Gulf, while Iran is likely to emerge as the primary sponsor of Hizbullah and other radical Islamist organizations, with the notable exception of HAMAS. The upshot is most likely to be "a very unstable [regional] system."

Morten Valbjørn and André Bank claim that the New Arab Cold War entails not only rivalries among Arab states but also "a stronger regime/society dimension, where the 'radical' block is dominated by societal actors advocating an Arab-Islamic order with considerable resonance within the Arab public." In this conceptual scheme, Iran during the administration of President Mahmoud Ahmadinejad was posited to act like a quintessential Arab state, since Ahmadinejad was regarded as a putative Arab nationalist by large numbers of Arabs. ${ }^{6}$ Curtis Ryan, by contrast, highlights the sectarian (that is, Sunni versus Shi'i) dimension of recent conflicts throughout the region, and suggests that the inordinate degree of influence that has been exerted by Qatar and Saudi Arabia reflects their respective leaderships' fear that Shi'i forces will be in a position to dominate the post-uprising Middle East. ${ }^{7}$

Reinoud Leenders distinguishes four types of connections among internal and external conflicts, which combine to produce what he calls a Middle Eastern regional conflict formation: military networks, political (that is, "personal") allegiances, economic and financial transactions ("especially those of an illicit nature"), and "shared identities [that transcend] national borders-primarily in terms of ethnic, sectarian and other "cultural identities." ${ }^{8}$ Leenders accords predominant weight to the last of these factors, arguing that "actors' strategies to effectively generate symbolic capital are often placed in the context of regional developments or events beyond their immediate national borders, thereby affecting people's [that is, the politically active public's] perceptions and understandings of politics and violence in multiple locations." In later work, he adds that ideological/discursive factors can be expected to interact with the dynamics

\footnotetext{
${ }^{4}$ Ibid., 75.

${ }^{5}$ Morten Valbjørn and André Bank, "The New Arab Cold War: Rediscovering the Arab Dimension of Middle East Regional Politics," Review of International Studies 38, no. 1 (January 2012): 5. See also Morten Valbjørn and André Bank, "Signs of a New Arab Cold War: The 2006 Lebanon War and the Sunni-Shi'i Divide," Middle East Report no. 242 (Spring 2007): 6-11.

${ }^{6}$ Valbjørn and Bank, "The New Arab Cold War," 17.

${ }^{7}$ Curtis Ryan, “The New Arab Cold War and the Struggle for Syria," Middle East Report no. 262 (Spring 2012): 28-31.

${ }^{8}$ Reinoud Leenders, “Regional Conflict Formations': Is the Middle East Next?” Third World Quarterly 28, no. 5 (May 2007): 961-967.

${ }^{9}$ Ibid., 969.
} 
of state formation and consolidation to create distinctive constellations of domestic and foreign conflict across the region. ${ }^{10}$

Instead of focusing primarily on identity and discourse, it seems more apposite to explain current trends in the Middle Eastern RSC by tracing out the ways in which domestic political conflicts generate interconnected security externalities throughout this part of the world. Heightened levels of interstate friction and rivalry that have arisen as a result of escalating internal struggles have prompted governments to adopt belligerent policies toward one another that they might not otherwise have chosen. The conjunction of internally-generated, antagonistic external initiatives has triggered intersecting conflict spirals and kaleidoscopic changes of strategic alignment that are all but impossible to explain in terms of the rational pursuit of state interest.

\section{The Middle Eastern RSC on the Eve of the Syrian Uprising}

In the years leading up to the fateful winter of 2010-11, changes in the Middle Eastern regional security complex were driven largely by strategic initiatives undertaken by the governments of Syria and Israel. Foreign policies that were adopted by these two states in an effort to ameliorate deteriorating circumstances in their respective domestic political-economic arenas ended up heightening the level of conflict throughout the region, while at the same time drawing new players into regional affairs.

\section{Syria Aligns with Iraq and Turkey}

After the dismantling of the Ba'thi regime in Iraq in 2003-04, Syria's position in regional affairs rapidly deteriorated. So long as Saddam Hussein remained in power in Baghdad, Damascus found itself able to take advantage of Iraq's impotence and isolation by boosting bilateral trade, acting as a major outlet for Iraqi oil exports, and offering guarded sympathy for Iraq's efforts to resist United States intervention in the Gulf. More important, Iraq's overall weakness made it possible for Syria to construct a loose coalition consisting of Iraq, Lebanon, Jordan, and Iran to offset the rival IsraelTurkey axis. This coalition could only succeed so long as Baghdad refrained from undertaking initiatives that might aggravate its putative allies, and Israel remained sufficiently reassured to hold itself back from launching preventive military operations.

Syria did its best to preserve strategic ties to Iraq after the ouster of the Ba'thi regime in Baghdad. President Bashar al-Assad welcomed Iraq's prime minister and deputy prime minister for security affairs to Damascus in July 2004, and advanced a number of proposals to strengthen mutual relations. The new Iraqi government quickly

10 Reinoud Leenders, "Strong States in a Troubled Region: Anatomies of a Middle Eastern Regional Conflict Formation,” Comparative Social Research 27 (2010): 171-195. 
focused its attention on Tehran, however, and let security and economic connections with Damascus stagnate. In response, Syria undertook to reinvigorate its strategic partnership with Iran. Plans were drawn up to create a free trading zone between the two countries, and in February 2005 Iranian Vice President Muhammad Reza Aref declared that the two states had concluded a mutual defense pact. ${ }^{11}$

At the same time, Syria made a concerted effort to improve relations with Turkey. ${ }^{12}$ Damascus's commitment to rapprochement with Ankara deepened following Saddam Hussein's overthrow. The Syrian interior minister met with the chief of Turkey's gendarmerie in December 2003 to discuss ways that the two countries might work together to enhance cross-border security. A month later, President al-Assad journeyed to the Turkish capital; Turkey's Prime Minister Recep Tayyip Erdoğan reciprocated at the end of the year, and the two leaders signed a free trade agreement that promised to augment bilateral commercial and financial transactions.

Damascus's pronounced warming to Ankara set off alarm bells in Israel, whose leaders ratcheted up their anti-Syria rhetoric. ${ }^{13}$ In a bid to disrupt burgeoning SyrianTurkish amity, the Israeli air force attacked an abandoned training camp of the Popular Front for the Liberation of Syria-General Command (PFLP-GC) outside Damascus in October 2003. At the same time, the heightened mobilization of the Shi' $i$ population of southern Iraq generated closer and more sustained interactions between the Iraqi Shi'a and the Shi'a of southern Lebanon. Direct linkages between the Lebanese Shi'a and the Shi'i seminary and pilgrimage centers of Najaf and Karbala weakened Syria's grip on the Lebanese Shi'a in general, and reduced its leverage visà-vis Hizbullah in particular.

Damascus's declining influence over Hizbullah accompanied a pivotal shift in that movement's political platform. Led by Secretary General Hassan Nasrallah, the party made overtures to influential figures in Lebanon's diverse Christian communities as a way to broaden its electoral base. This change of strategy stirred up discontent among militants inside the organization, who gravitated toward former Secretary General Subhi al-Tufaili and started to agitate for a return to Hizbullah's militant program. Confronted with rising criticism inside the movement, Nasrallah expressed unqualified support for Palestinian activists when the al-Aqsa uprising (intifada) broke out in September 2000. Hizbullah fighters stepped up military activities along the

\footnotetext{
${ }^{11}$ Fred H. Lawson, Global Security Watch Syria (Santa Barbara, CA: Praeger, 2013), 133.

${ }_{12}$ Fred H. Lawson, ed., "The Beginning of a Beautiful Friendship: Syrian-Turkish Relations since 1998," in Demystifying Syria (London: Saqi Books, 2009), 180-205.

${ }_{13}$ Tanya Reinhart, The Road Map to Nowhere (London: Verso, 2006).
} 
Lebanon-Israel border over the next two years, prompting the Israel Defense Force (IDF) in April 2002 to bomb a Syrian radar facility located deep inside Lebanon's eastern Biqa 'Valley.

Tensions along Israel's northern border flared so dramatically during the spring of 2002 that Iranian Foreign Minister Kamal Kharrazi made an emergency trip to Beirut. He warned the leadership of Hizbullah to restrain its armed wing, Saraya al-Muqawamah al-Islamiyyah (Islamic Resistance Companies), from launching any further raids against Israeli outposts, on the grounds that such attacks placed Palestinian civilians in the West Bank and Gaza in jeopardy. Following Kharrazi’s visit, Hizbullah did indeed scale back its armed operations, and the Islamic Resistance Companies thereafter confined themselves to shooting at Israeli aircraft and warships whenever they crossed into Lebanese airspace or territorial waters.

Hizbullah's shift toward moderation in foreign policy fueled further discontent among the militants clustered around al-Tufaili. The radical wing of the party expressed contempt for both Syria and Iran, and blamed Tehran in particular for doing the bidding of the United States by helping to suppress Islamist fighters in Iraq and Afghanistan. Hizbullah's turn toward moderation also set the stage for the emergence of the radical, predominantly Sunni, Hizb al-Tahrir (Liberation Party). This organization had been kept in check by the Syrian security forces, but was accorded legal status in Lebanon following the February 2005 assassination of Rafiq Hariri. The Liberation Party castigated Hizbullah for abandoning the quest to establish an Islamic republic in Lebanon, and appealed to disaffected Shi'a to join it in a revived crusade to construct a political system firmly rooted in religious doctrine. At the same time, an assortment of Sunni radicals coming from Iraq infiltrated into Lebanon, banded together under the name al-Qaida fi Bilad al-Sham (al-Qa'ida in the Lands of Syria), and pledged to take up the armed struggle (jihad) against Israel where Hizbullah had left off. ${ }^{14}$

Challenges to Hizbullah's leadership became more pressing after Syrian troops pulled out of Lebanon in April 2005. The mainstream of the party found itself increasingly on the defensive as key figures of Lebanon's Maronite and Druze communities insisted that it take steps to disarm the Islamic Resistance in order to comply with United Nations Security Council Resolution 1559.15 In February 2006, an alliance of radical Islamist groups orchestrated a mass demonstration in Beirut to demand a fundamental restructuring of the country's political system. The protest was

\footnotetext{
${ }^{14}$ Leenders, "Regional Conflict Formations," 963.

15 Bassel Salloukh, "Syria and Lebanon: A Brotherhood Transformed," Middle East Report no. 236 (Fall 2005 ): 14-21.
} 
instigated by Sunni militants based in Lebanon's northern district of Diniyyah, whose adherents had revolted against the country's Syrian-backed regime six years earlier.

Under these circumstances, radical Palestinian organizations joined Hizbullah fighters in probing the limits of IDF forbearance along the Lebanon-Israel border. PFLP-GC guerrillas had already carried out a series of cross-border strikes during the summer and fall of 2002. In May 2005, renewed attacks were launched against several IDF outposts. Israeli forces responded by shelling villages inside Lebanese territory; Hizbullah retaliated by firing rockets into Israel proper. The escalating conflict constituted a clear violation of the informal rules of engagement that had governed the confrontation between Hizbullah and Israel, and eventually convinced Israeli commanders to draw up plans for a military offensive intended to eliminate all security threats emanating from the north. ${ }^{16}$

\section{Israel Advances into the Caucasus and Central Eurasia}

Meanwhile, Israeli officials attempted to solve the country's persistent economic problems through a two-pronged strategy of imposing severe cuts in public expenditure and expanding overseas markets for Israeli manufactured goods. The reductions in state spending provoked fierce opposition from organized labor (the Histadrut) and proponents of government support for the disadvantaged (the SHAS movement) alike, giving state officials a strong incentive to find new buyers for Israeli electronic equipment and telecommunications systems, along with the sophisticated weapons produced by Israel's highly-capitalized armaments industry. Israeli technology companies became involved in oil-rich Azerbaijan in the late 1990s, and Israeli contractors took a predominant role in the drive to modernize that country's armed forces. ${ }^{17}$ The prospect of greater Israeli involvement in Azerbaijan led senior officials in Tehran to accuse the authorities in Baku of collaborating with the United States and its regional clients to undercut local control of the oil resources around the Black Sea. ${ }^{18}$

Israel targeted other former Soviet republics as well. Kazakhstan and Uzbekistan attracted substantial amounts of investment in agricultural projects during the late 1990s. ${ }^{19}$ A jump in Israeli trade with the two countries quickly followed. ${ }^{20}$ Heightened

\footnotetext{
${ }^{16}$ Eyal Zisser, "Hizballah and Israel: Strategic Threat on the Northern Border," Israel Affairs 12, no 1 (January 2006): 86-106.

${ }^{17}$ Ilya Bourtman, "Israel and Azerbaijan's Furtive Embrace," Middle East Quarterly 13, no. 3 (Summer 2006): 47-57.

${ }^{18}$ Fariz Ismailzade, “Azerbaijani-Iranian Relations Endangered after Russian Publication,” Central Asia-Caucasus Institute Analyst, June 4, 2003, http://old.cacianalyst.org/?q=node/1208.

${ }^{19}$ Jacob Abadi, “Israel's Quest for Normalization with Azerbaijan and the Muslim States of Central Asia," Journal of Third World Studies 19, no. 2 (Fall 2002): 63-88.

${ }^{20}$ Michael B. Bishku, "The Relations of the Central Asian Republics of Kazakhstan and Uzbekistan with Israel," Middle Eastern Studies 48, no. 6 (November 2012): 933-934.
} 
economic cooperation included Israeli training missions tasked with improving the two governments' fiscal and regulatory procedures, sometimes in conjunction with advisers from the US Agency for International Development. As radical Islamist groups became more active in both the North Caucasus and Central Eurasia after 2001, Israel supplied arms and technical assistance to military and police forces throughout the region as well. These initiatives played a crucial role in restoring a modicum of health to the Israeli economy.

Nevertheless, Israel's Prime Minister Ariel Sharon faced a burgeoning internal crisis during the second half-decade of the twenty-first century. The government's February 2004 announcement that the IDF was going to disengage from Gaza and three troublesome districts of the West Bank sparked heated protests from Jewish settlers and radical right-wing organizations. Opponents of withdrawal sharpened their protests in early 2005, and kept the pressure up until parliamentary elections took place in March 2006. Throughout the electoral campaign, the IDF engaged in largescale operations in Gaza, which ended up provoking a rocket strike by HAMAS on Israeli territory that July. Skirmishing persisted into the fall of 2005, accompanied by a growing determination on the part of IDF commanders to inflict collective punishment on Gaza's residents for actions undertaken by HAMAS militants.

Israeli policymakers adopted a harder line against HAMAS in the wake of the January 2006 legislative elections in the zone formally administered by the Palestinian Authority. HAMAS candidates came away with 74 of 132 seats in the new popular assembly, and gained control of the Authority's Council of Ministers. On the advice of the Israeli General Staff, incoming Prime Minister Ehud Olmert authorized a massive redeployment of IDF units back into Gaza that June, then unleashed a combined air, ground, and naval assault on southern Lebanon after Hizbullah radicals abducted an Israeli soldier along the northern border a month later. Saudi Arabia and Egypt laid blame for the fighting squarely on Hizbullah, charging that it had provoked the IDF by engaging in "irresponsible adventurism. ${ }^{21}$ Egypt's Muslim Brothers, by contrast, joined the civil rights activists of the Kifaya movement (Enough movement) in expressing unqualified support for Hizbullah.

Syria stayed largely neutral during the 2006 Hizbullah-Israel war, and hinted shortly afterwards that it was willing to resume peace talks with Israel. These overtures were flatly rejected by Israeli officials, who alleged that Damascus had provided Hizbullah with missiles and other heavy weaponry and must pledge to stop doing so in future before talks could be resumed. In September 2006, IDF warplanes bombed

${ }^{21}$ Amr Hamzawy, "Adventurism versus Submission," al-Ahram Weekly, July 27-August 2, 2006, http://weekly. ahram.org.eg/2006/805/op121.htm. 
a suspected nuclear facility outside the eastern Syrian city of Dair al-Zur. Infuriated, Syrian officials terminated the peace initiative and ramped up their anti-Zionist rhetoric. The heightened potential for Syrian-Israeli conflict persuaded Turkey to step in and mediate between the two states. Informal discussions under Turkish auspices took place throughout $2007-08$, and were scheduled to culminate in a summit meeting in Istanbul in December 2008.

\section{Turkey Makes Overtures to Iraq and Iran}

Officials in Ankara also prosecuted a campaign during 2007-08 to build bridges to Iraq. The overtures aimed not only at improving relations with the central government in Baghdad and propping up the Turkoman minority in Iraq's northern provinces, but also at cultivating ties to Iraq's fractious Kurdish communities. ${ }^{22}$ Proposals to augment Turkish trade and investment in the districts administered by the Kurdistan Regional Government (KRG) were enthusiastically reciprocated, and more than a thousand Turkish companies started doing business in KRG territory. ${ }^{23}$ Working together, Ankara and the KRG exerted strong pressure on the Kurdistan Workers' Party (PKK) to abandon its thirty-year armed struggle against the Turkish Republic.

Ankara's simultaneous rapprochement with Baghdad and the KRG generated friction with Iran, which had exercised substantial influence in Iraqi affairs since the summer of 2004. Heightened Turkish involvement in Iraq coincided, however, with the emergence of a militant Iranian Kurdish movement, the Party for a Free Life in Kurdistan (PJAK), whose cadres set up training camps in the Qandil mountains of northern Iraq. This development provided Turkey and Iran with a basis for tactical collaboration, and in July 2004 the two countries concluded a mutual security pact that targeted both PJAK and the PKK. ${ }^{24}$ Local military officers subsequently coordinated their operations, and the Iranian authorities on occasion dispatched captured PKK fighters to Turkey for prosecution.

Turkish-Iranian relations received an unanticipated boost in late 2008 when Israel abruptly launched a large-scale military offensive against the Palestinian Authority's western district of Gaza without giving advance warning to Ankara. The scale of the destruction visited upon Gaza's civilian population provoked intense anger among the Turkish populace and appalled senior Turkish policymakers, thereby setting the stage for Prime Minister Erdoğan's vituperative condemnation of Israeli President

${ }^{22}$ Henri J. Barkey, “Turkey and Iraq: The Making of a Partnership,” Turkish Studies 12, no. 4 (December 2011): 668, doi: 10.1080/14683849.2011.622508.

${ }^{23}$ Ibid., 673.

${ }^{24}$ Gareth H. Jenkins, Occasional Allies, Enduring Rivals: Turkey's Relations with Iran (Washington, D.C.: Central Asia-Caucasus Institute and Silk Road Studies Program, May 2012), 33. 
Shimon Peres at the January 2009 World Economic Forum in Davos. Iran's President Mahmoud Ahmadinejad immediately thanked Erdoğan for his outburst, and Erdoğan returned the favor by congratulating Ahmadinejad on his own re-election five months later. ${ }^{25}$ During an official trip to Tehran that October, the Turkish prime minister called Iran's atomic research program "an exercise in nuclear energy, an exercise with peaceful and humanitarian goals." 26

Turkey's opening to Iran accompanied a dramatic shift in policy toward Armenia. Despite entreaties from Azerbaijan for Ankara to refrain from normalizing relations with Yerevan until a settlement could be reached in the long-running dispute over the enclave of Nagorno-Karabakh, Turkish and Armenian officials in October 2009 signed an agreement that opened the land border between the two countries and provided for the exchange of ambassadors. ${ }^{27}$ The treaty was welcomed by Russia and Georgia, but elicited hostile responses from both Baku and several Turkish nationalist parties, which considered it a betrayal of underlying Turkic interests. Azerbaijan riposted by announcing drastic cuts in oil and gas shipments to Turkey, along with a redirection of hydrocarbon exports toward Russia, Iran, and the People's Republic of China. ${ }^{28}$ More important, the normalization of relations between Turkey and Armenia sparked greater restiveness among the Armenian community of Samtskhe-Javakheti inside Georgia, whose activists had earlier restrained themselves in order to ensure the flow of vital imports into Armenia across Georgian territory. ${ }^{29}$ After the treaty was rejected by the Turkish national assembly in May 2010, Armenia and Azerbaijan assumed even more intransigent postures regarding the disposition of Nagorno-Karabakh. ${ }^{30}$

Heightened Turkish activism in the South Caucasus accompanied renewed Israeli initiatives in the North Caucasus. In March 2010, a high-ranking delegation from Chechnya arrived in Israel to discuss opportunities for bilateral trade and investment; two months later, the president of Kabardino-Balkaria followed suit to scout out areas of common interest. At the same time, Israeli companies expanded operations

\footnotetext{
25 Ibid., 37.

26 Ibid., 38.

27 Roman Muzalevsky, "The Armenia-Turkey Protocols: Tactical Cooperation in the Shadow of Eurasian Strategic Competition," Central Asia-Caucasus Institute Analyst, November 11, 2009, http://www.cacianalyst.org/ publications/analytical-articles/item/11942-analytical-articles-caci-analyst-2009-11-11-art-11942.html.

${ }^{28}$ Stephen Blank, "Nagorno-Karabakh: A Disaster in the Making?" Central Asia-Caucasus Institute Analyst, BiWeekly Briefing 11, no. 24 (December 23, 2009): 3-5, http://www.cacianalyst.org/publications/analytical-articles/ item/11971-analytical-articles-caci-analyst-2009-12-23-art-11971.html.

${ }^{29}$ Vahagn Muradyan, "Armenia and Georgia in the Context of Turkish-Armenian Rapprochement," Central AsiaCaucasus Institute Analyst, Bi-Weekly Briefing 12, no. 5 (March 17, 2010): 6-8, http://www.silkroadstudies.org/ new/docs/publications/100317analyst.pdf.

${ }^{30}$ Haroutiun Khachatrian, "Resumed Deadlock in the South Caucasus at the Anniversary of the Karabakh CeaseFire," Central Asia-Caucasus Institute Analyst, Bi-Weekly Briefing 12, no. 9 (May 13, 2010): 9-11, http://www. silkroadstudies.org/new/docs/publications/100512analyst.pdf.
} 
in Daghestan, in open defiance of the simmering conflict between the authorities and Islamist militants. ${ }^{31}$ Military ties between Israel and Azerbaijan expanded dramatically, laying the foundation for a local Azerbaijani armaments industry capable of producing drone aircraft and other sophisticated weapons. ${ }^{32}$

\section{Turkey and Israel Fall Out with One Another}

As Ankara and Jerusalem launched simultaneous diplomatic and economic offensives in the Caucasus, the Turkey-Israel axis imploded. Strains in the alliance had appeared as early as December 2005, when reports surfaced that retired IDF personnel were training PKK cadres in northern Iraq. ${ }^{33}$ In November 2008, the Turkish government announced plans to send humanitarian aid to Gaza to offset the damage inflicted by the Israeli-Egyptian blockade, and Erdoğan expressed sympathy not only for Palestinian civilians but also for HAMAS, whose electoral victory had not been "respected" by the international community during and immediately after the December 2008 war. $^{34}$ When the fighting ended, Erdoğan embarked on a tour of Syria, Jordan, Saudi Arabia, and Egypt to solicit material assistance for HAMAS; he pointedly avoided visiting Israel, even as his senior foreign policy adviser conferred with HAMAS's military commander in Damascus. By the time that IDF commandos stormed the Turkish relief ship Mavi Marmara (Blue Marmara) off the coast of Gaza in June 2010, the strategic partnership between the two governments had all but evaporated.

While the Turkey-Israel axis disintegrated, Ankara's relations with Damascus and Tehran strengthened. The first joint Syrian-Turkish military exercises took place in April 2009; six months later, the two states signed an agreement that permitted citizens to cross the border without obtaining a visa. At that point, Syria's Foreign Minister Walid al-Moualem remarked that his government "considers the PKK a terrorist organization. Turkey's security is part of Syria's security." 35 A delegation of highranking Iranian security officials met with Erdoğan and Turkish President Abdullah Gül in January 2009 to work out ways to coordinate regional backing for HAMAS. ${ }^{36}$ That fall, the two countries agreed to collaborate to exploit the Iranian oilfields of

31 Dmitry Shlapentokh, "Kadyrov's Contacts with Israel and the Jihadist Threat," Central Asia-Caucasus Institute Analyst, Bi-Weekly Briefing 12, no. 9 (May 13, 2010): 6-8, http://www.silkroadstudies.org/new/docs/ publications/100512analyst.pdf.

${ }^{32}$ Eldar Mamedov, “How Deep are Azerbaijan-Israel Relations?” EurasiaNet.org, January 18, 2013, http://www. eurasianet.org/node/66431.

${ }_{33}$ Banu Eligür, "Crisis in Turkish-Israeli Relations (December 2008-June 2011): From Partnership to Enmity," Middle Eastern Studies 48, no. 3 (May 2012): 431, doi: 10.1080/00263206.2012.662893.

${ }^{34}$ Ibid., 435.

${ }^{35}$ Ibid., 442.

${ }^{36}$ Ibid., 437. 
South Pars, set up an industrial free-zone along the border, and made it possible for banks based in one country to operate in the other. Most strikingly, Turkish officials revised the National Security Policy Paper in the fall of 2010 in such a way as to remove the Islamic Republic of Iran from the list of external threats facing the country. ${ }^{37}$ That October, military aircraft from the People's Republic of China joined the Turkish air force in aerial maneuvers over Turkey's central Konya province, with logistical support from Iran. ${ }^{38}$

In line with its new anti-Israel alignments, Ankara made persistent overtures to Hizbullah during 2010. Secretary General Nasrallah was formally invited to visit Turkey that summer, and Prime Minister Erdoğan telephoned the Hizbullah leader to offer condolences at the death of the movement's spiritual adviser, Ayatollah Muhammad Hussein Fadlallah. ${ }^{39}$ Continued expressions of sympathy for, and official linkages to, HAMAS precipitated a brief crisis in Turkey's relations with Egypt in January 2010. Such actions accompanied Ankara's unprecedented opening to the Kurdistan Workers' Party, which included the granting of amnesty to three dozen activists who had returned to Turkey from several European countries in October 2009.40 The arrival of the PKK émigrés sparked public celebrations among the Kurds of southeastern Anatolia, along with anti-government protests on the part of Turkish ultra-nationalists, which together persuaded state officials to put the so-called "Kurdish spring" under tighter control. Erdoğan's efforts during the summer of 2010 to revive the campaign to weaken the PKK deliberately bypassed the Kurdish Peace and Democracy Party (BDP).

Ankara's abortive opening to the Kurdish population of Anatolia occurred in the context of escalating tensions between the Kurdistan Regional Government and the central administration in Baghdad. The contest largely reflected long-standing conflicts of interest over the oil-producing areas around Kirkuk. ${ }^{41}$ It also entailed a fiveway struggle among the Kurdistan Democratic Party (KDP), the Patriotic Union of Kurdistan (PUK), an assortment of Sunni Islamist movements, Shi'i radicals affiliated with Muqtada al-Sadr, and the predominantly Shi'i I'tilaf Dawlat al-Qanun (State of Law Coalition) headed by Iraqi Prime Minister Nuri al-Maliki. In this intricate

\footnotetext{
37 Ibid., 448.

${ }^{38}$ Ibid.; Efraim Inbar, The Deterioration in Israeli-Turkish Relations and its International Ramifications, Mideast Security and Policy Studies 89 (Ramat Gan: Begin-Sadat Center for Strategic Studies, Bar-Ilan University, February 2011), 5, http://www.biu.ac.il/Besa/MSPS89.pdf.

${ }^{39}$ Inbar, Deterioration in Israeli-Turkish Relations, 7.

${ }^{40}$ Ofra Bengio, “The 'Kurdish Spring' in Turkey and its Impact on Turkish Foreign Relations in the Middle East," Turkish Studies 12, no. 4 (December 2011): 623, doi: 10.1080/14683849.2011.622509.

${ }^{41}$ Michael M. Gunter, "Arab-Kurdish Relations and the Future of Iraq," Third World Quarterly 32, no. 9 (October 2011): 1626-1627, doi: 10.1080/01436597.2011.618649.
} 
game, the KDP and PUK found themselves losing political clout during 2008-09. Faced with increasingly bleak prospects, the two parties' militias adopted overtly belligerent stances toward the Iraqi armed forces, precipitating a succession of armed confrontations along the border between the KRG and the rest of Iraq. ${ }^{42}$ Clashes also broke out between the PUK and supporters of the Gorran movement (Change movement) whose members defected from the PUK in the weeks leading up to the March 2010 parliamentary elections. ${ }^{43}$

Turkish policymakers recognized the security implications of a resumption of Kurdish bellicosity against the authorities in Baghdad, and took somewhat hamfisted steps to defuse tensions inside Iraq. Turkey's ambassador to Iraq did his best to dampen the polarization of Iraqi politics along sectarian lines by trying to block the reappointment of Prime Minister al-Maliki in the wake of the March elections, and Turkish officials subsequently invited al-Maliki's primary rival, Iyad 'Allawi of the electoral alliance known as al-Qa'imah al-'Iraqiyyah (Iraqi List), to Ankara for high-level consultations. ${ }^{44}$ Turkish representatives also sponsored a variety of Sunni political movements in the northwestern provinces of Iraq, most notably the so-called al-Hadba' bloc, which played a crucial role in undermining the electoral strength of both the KDP and PUK. ${ }^{45}$

Turbulence inside the KRG tempted Iran to intervene in Iraq's domestic affairs as well. The Islamic Revolutionary Guards Corps (IRGC) carried out a large-scale artillery and ground attack against PJAK bases in the northern provinces in June 2010, then constructed a permanent military outpost on Iraqi territory adjacent to the border town of Perdunaz. ${ }^{46}$ Skirmishing between IRGC and PJAK units continued throughout the summer. ${ }^{47}$

\section{Initial Impact of the Syrian Uprising}

At the same time that protesters in Cairo's Midan Tahrir (Liberation Square) clamored for the resignation of Egyptian President Hosni Mubarak, adherents of the Change movement took to the streets of the northern Iraqi city of Sulaimaniyyah

\footnotetext{
${ }^{42}$ Ibid., 1628.

${ }^{43}$ Leila Fadel, “Clashes in Iraq's North Underscore Fierce Political Rivalry,” Washington Post, March 5, 2010. http://www.washingtonpost.com/wp-dyn/content/article/2010/03/04/AR2010030405153.html.

${ }_{44}$ Al-Akbbar, March 27, 2010; al-Safir, April 29, 2010; Sean Kane, The Coming Turkish-Iranian Competition in Iraq, Special Report 276 (Washington, D.C.: United States Institute of Peace, June 2011, 9).

${ }^{45}$ Kane, Coming Turkish-Iranian Competition; Gunter, “Arab-Kurdish Relations,” 1627.

46 Al-Hayah, June 7, 2010; Asso Ahmed, "Iranian Troops Building Fort in Iraq," Los Angeles Times, June 8, 2010, http://articles.latimes.com/2010/jun/08/world/la-fg-iraq-iran-incursion-20100609.

${ }^{47}$ Guillaume Perrier, "Iraqi-Based Kurdish Guerrillas do Battle with Tehran," The Guardian, August 31, 2010, http://www.theguardian.com/world/2010/aug/31/iran-kurdish-guerrillas-battle.
} 
to demand an end to the joint dominance of the Kurdistan Democratic Party and the Patriotic Union of Kurdistan over the Kurdistan Regional Government. The protests spread rapidly to other cities and gained momentum during February and March 2011. KDP fighters responded by shooting into the crowds and torching the Change movement's offices. ${ }^{48}$ When it became clear that local security forces could not contain the demonstrations, the KRG authorities promulgated a directive that banned all public protests. ${ }^{49}$ Escalating disorderliness across northern Iraq prompted the Islamic Revolutionary Guards Corps to step up its attacks on villages suspected of harboring PJAK fighters. In July 2011, Tehran deployed some 5,000 troops along the border, and a month later Turkey's armed forces resumed large-scale military operations inside KRG territory as well, after PKK militants struck a military post near the city of Diyarbakir in southeastern Anatolia. ${ }^{50}$ Fighting persisted on both fronts that September and October. ${ }^{51}$

\section{Syrian Protests Disrupt Relations with Neighbors}

Anti-regime protests in Syria initially prompted Turkey, Iran, and Iraq to rally behind President al-Assad. Iranian officials pledged to boost trade and investment in order to help the Syrian government deal with festering popular discontent, while Turkish Prime Minister Erdoğan welcomed the nominal reform measures that were introduced by the $\mathrm{Ba}$ 'thi leadership in March and April as significant steps in the right direction. ${ }^{52}$ When the confrontation between opponents and supporters of the Syrian regime turned violent, however, and the authorities in Damascus resorted to indiscriminate force in an attempt to suppress the protests, Ankara abruptly pulled away from the Ba'thi leadership. Turkish Foreign Minister Ahmet Davutoğlu made a final plea to President al-Assad to restrain his supporters in early August, to no avail. ${ }^{53}$ Two weeks later, Syrian troops signaled the cooling of bilateral relations by installing anti-aircraft batteries outside the border town of Kassab to deal with any potential incursion by Turkish warplanes.

\footnotetext{
${ }^{48}$ Gunter, “Arab-Kurdish Relations," 1625.

49 "Seizing on Egypt Tumult, Kurdish Splinter Party Calls on Iraqi Regional Government to Resign," Associated Press, January 29, 2011; "Iraqi Kurdish Authorities Ban Protests in Province," Agence France Presse, April 19, 2011.

${ }^{50}$ Daniel Dombey and Funja Guler, “Turkey Hits Kurdish Targets in Iraq," Financial Times, August 19, 2011.

51 “Iran Says Kills 30 Kurd Rebels in New Border Push," Reuters, September 3, 2011, http://www. reuters.com/article/2011/09/03/us-iran-kurds-operation-idUSTRE7821G120110903;

Presses Ahead with PKK Offensive," Al Jazeera, October 20, 2011, http://www.aljazeera.com/news/ middleeast/2011/10/201110221411345914.html.

${ }^{52}$ Lawson, Global Security Watch Syria, 141.

${ }^{53}$ André Bank, "Turkey and the Arab Revolt: Rise or Decline in Regional Politics?” GIGA Focus 4, German Institute of Global and Area Studies, Berlin, 2011, 6, http://www.giga-hamburg.de/en/system/files/publications/ gf_international_1104.pdf.
} 
In April 2012, Erdoğan warned that Turkey would "implement steps" to deal with the violence in Syria if United Nations efforts failed to end the bloodshed. The day after the prime minister's warning, Syrian forces shot across the border into a refugee camp outside Killis; Erdoğan then intimated that the Turkish armed forces would set up safe havens inside Syrian territory to shelter the growing number of displaced persons. ${ }^{54}$ Ankara's belligerence redoubled after Syrian gunners shot down a Turkish reconnaissance aircraft flying over Hatay in mid-June 2012; additional troops took up positions along the border, and were given orders to consider any move in their direction by Syrian forces as a hostile act. Rising Turkish antagonism toward Damascus spilled over into heightened mistrust of Iran, whose government continued to provide material and moral support to the al-Assad regime..$^{55}$

During the winter of 2012-13, radical Islamist formations seized the initiative in the Syrian civil war. Primary among these were the Jabhat al-Nusrah li-Ahl alSham (Assistance Front for the People of Syria), Kata'ib Ahrar al-Sham (Battalions of the Free of Syria), and Suqur al-Sham (Brigade of Syrian Falcons). Foreign fighters filled the ranks of other radical militias, most notably Liwa' al-Ummah (Brigade of the Community of Believers), and Harakat Fajr al-Islam (Dawn of Islam Movement). These disparate formations operated almost entirely independently, and on occasion came into direct conflict with one another. At the end of 2012, Kata'ib Ahrar al-Sham (Battalions of the Free of Syria) announced a tactical alliance with the Harakat Fajr alIslam (Dawn of Islam Movement) and several smaller formations, which called itself al-Jabha al-Islamiyyah al-Suriyyah (Syrian Islamic Front). Suqur al-Sham (Brigade of Syrian Falcons) riposted by joining Liwa' al-Faruq (al-Faruq Brigade) and Liwa' alIslam (the Islam Brigade) to form a rival Jabhat al-Tahrir al-Islami (Islamic Liberation Front). The two blocs subsequently competed against each other to win popular support by distributing bread and cooking oil to embattled neighborhoods.

As radical Islamist formations pushed troops loyal to the regime out of districts across northern and northwestern Syria, their cadres assaulted residents who belonged to minority communities, particularly 'Alawites, Shi'a, and Christians. Islamist fighters seized control of the city of al-Raqqah in January 2013 and immediately ransacked the Shi' $i$ mosques that had been renovated with financial support from Iran and that attracted large numbers of pilgrims from Lebanon, Iraq, and the Islamic Republic. ${ }^{56} \mathrm{In}$

\footnotetext{
${ }^{54}$ Ibid., 143.

${ }^{55}$ Yigal Schleifer, “Turkey and Iran: Amidst the Smiles, A Rivalry Intensifies,” EurasiaNet.org, February 23, 2012, http://www.eurasianet.org/node/65040.

${ }^{56}$ Firas al-Hakkar, “The Mysterious Fall of Raqqa, Syria’s Kandahar," al-Akhbar English, November 8, 2013, http:// english.al-akhbar.com/node/17550; Myriam Ababsa, "The Shi'i Mausoleums of Raqqa: Iranian Proselytism and Local Significations," in Demystifying Syria, ed. Fred H. Lawson (London: Saqi Books, 2009), 85-104.
} 
early May 2013, a unit of the Free Syrian Army (FSA) desecrated the tomb of Hajr bin 'Adai, a companion of the Prophet Muhammad who is especially revered by the Shi'a, and made off with his body. Photographs of the empty grave were posted on Facebook with the provocative caption: "This is one of the Shiite shrines in Adra which the heroes of the Free Syrian Army exhumed and reburied in an unknown location since it had become a centre of polytheism. ${ }^{57}$

Shi'i villagers west of Homs organized to protect themselves from radical Islamist militias as the spring of 2013 went by. Their efforts elicited assistance from Hizbullah, whose cadres provided arms and training to local fighters. At the same time, predominantly 'Alawi contingents of the regime-sponsored National Defense Forces proliferated throughout the coastal mountains between Tartus and Latakia. ${ }^{58}$ Animosity between the Jabhat al-Nusrah li-Ahl al-Sham (Assistance Front for the People of Syria) and the Druze community of the southern province of al-Suwaida escalated in the wake of a string of kidnappings of Druze civilians by Islamist militants in villages adjacent to opposition-controlled parts of neighboring Dir'a province.

Radical Islamist assaults against Shi'a, 'Alawites, and Isma'ilis persuaded Iraqi Shi'a to come to the defense of their sectarian comrades and the major Shi' $i$ monuments located inside Syria. The recruits generally passed through the ranks of 'Asa'ib Ahl al-Haqq (Bands of the People of Truth), a radical Iraqi Shi'i movement loosely allied to I'tilaf Dawlat al-Qanun (State of Law Coalition), although some were attached to rival organizations like the former Jaish al-Mahdi (Mahdi Army) or Munazzamat Badr (the Badr Organization). Most of the volunteers became inspired to embark upon the crusade by prominent Shi'i preachers, many of whom openly denounced the al-Maliki government's comparative moderation regarding sectarian issues. Increased involvement in Syria by armed Iraqi Shi'a complemented sharply rising levels of sectarian antagonism inside Iraq itself. Bombings of Sunni mosques became increasingly frequent and widespread occurrences by the spring of $2013 .{ }^{59}$

Recurrent Islamist assaults and growing Iraqi involvement in the Syrian civil war prompted Syria's far-flung Kurdish community to mobilize to defend itself. The great majority of Syrian Kurds had adopted a noncommittal stance during the

\footnotetext{
57 “Syrian Rebels 'Exhume' Grave of Islamic Figure," Gulf News, May 2, 2013, http://m.gulfnews.com/news/ region/syria/syrian-rebels-exhume-grave-of-islamic-figure-1.1178665.

${ }^{58}$ Fehim Tastekin, "Dreaming of 'Zion' on the 'Alawis Behalf," Radikal, May 27, 2013; Aziz Nakkash, The Alawite Dilemma in Homs: Survival, Solidarity and the Making of a Community (Berlin: Friedrich-Ebert-Stiftung, March 2013), http://library.fes.de/pdf-files/iez/09825.pdf.

${ }^{59}$ Tim Arango and Michael R. Gordon, "Sectarian Strains Pit Some Iraqis against their own Leaders," New York Times, March 19, 2013, http://www.nytimes.com/2013/03/20/world/middleeast/fading-hopes-of-unity-iniraq-as-sectarian-tensions-rise.html?_r=0; Ned Parker, "Iraq Violence Sparks Fear of a Sunni Revolt," Los Angeles Times, April 24, 2013, http://articles.latimes.com/2013/apr/23/world/la-fg-iraq-protests-20130424.
} 
first months of the uprising, so early rounds of the civil war spared the northeastern plains surrounding the cities of al-Hasakah and al-Qamishli. Toward the end of 2011, however, the authorities in Damascus acquiesced in, and perhaps even encouraged, the rise of a radical Kurdish organization that soon became active across the northeast. The Democratic Union Party (PYD), which enjoyed close ties to the PKK, took charge of a broad zone stretching from Ras al-'Ain on the Euphrates River to the Iraqi border. Clashes between the armed wing of the PYD, the Popular Protection Units (YPG), and various opposition militias became more numerous and intense during the winter of 2012-13. The sharp escalation in fighting led YPG fighters to seize major oilfields outside al-Hasakah, while units of the Free Syrian Army took control of oil-producing facilities around Dair al-Zur.

To make matters even more explosive, the PYD almost immediately became locked in a bitter contest with other parties inside Syria's Kurdish community. A major fault line divided the PYD from the Kurdish National Council, whose components were closely connected to the Kurdistan Democratic Party of northern Iraq. In July 2012, the two camps agreed to put aside their differences and work together to administer the areas that had fallen outside of Damascus's control. Nevertheless, the terms of the so-called Irbil Agreement reflected the comparative strength of the PYD, and failed to allay fundamental misgivings harbored by its rivals. ${ }^{60} \mathrm{YPG}$ commanders in September 2012 boasted that they had no intention of obeying orders issued by the newly-formed Higher Kurdish Council. ${ }^{61}$ In early February 2013, there were reports that fighters loyal to the PYD had clashed with members of the Kurdish Unity Party (Yakiti) around al-Qamishli. ${ }^{62}$ The potential for intra-Kurdish violence was augmented by the fact that PYD leaders exercised no more than loose and intermittent control over the Popular Protection Units. Moreover, the authorities in Damascus granted permission for the long-time chief of the Kurdistan Workers' Party in Syria, Salih Muslim, to return from the Qandil mountains in northern Iraq and resume his activities inside Syrian territory. ${ }^{63}$

\footnotetext{
${ }^{60}$ Ilhan Tanir, Wladimir van Wilgenburg, and Omar Hossino, Unity or PYD Power Play? Syrian Kurdish Dynamics after the Erbil Agreement (London: Henry Jackson Society Papers, July 2012), http://henryjacksonsociety.org/wpcontent/uploads/2012/10/HJS_Unity-or-PYD-Power-Play_-Report.pdf.

${ }^{61}$ Josh Wood, "In Syria, Kurds Carve out Territory of Their Own," Al-Monitor, October 4, 2012, http://www. al-monitor.com/pulse/originals/2012/al-monitor/syria-kurds-derek-protest.html; International Crisis Group, "Syria's Kurds: A Struggle Within a Struggle," Middle East Report no. 136 (January 22, 2013): 33, http://www. crisisgroup.org/en/regions/middle-east-north-africa/egypt-syria-lebanon/syria/136-syrias-kurds-a-strugglewithin-a-struggle.aspx.

${ }^{62}$ Heiko Wimmen and Muzehher Selcuk, “The Rise of Syria’s Kurds," Sada, Carnegie Endowment for International Peace, February 5, 2013, http://carnegieendowment.org/sada/2013/02/05/rise-of-syria-s-kurds/fcsw.

${ }^{63}$ Gonul Tol, “The Kurdish Dimension to Turkey's Syria Policy," Foreign Policy, April 10, 2012, http://mideastafrica. foreignpolicy.com/posts/2012/04/10/the_kurdish_issue_in_turkey_s_syria_policy.
} 
Across the border in Iraq, skirmishing among rival Kurdish parties intersected with a revived campaign on the part of the authorities in Baghdad to extend the reach of the central government into the territory administered by the Kurdistan Regional Government. In March 2011, Prime Minister al-Maliki ordered all Kurdish forces to withdraw from Kirkuk, following a wave of protests on the part of local Turkomans and Arabs against the Kurdish administration. ${ }^{64}$ Kurdish commanders refused to comply, arguing that their fighters were protecting the vital oil-producing region around Kirkuk from militant Islamists affiliated with al-Qaida. The crisis escalated when Turkey's deputy foreign minister arrived in the KRG capital of Irbil to confer with the KRG president; Foreign Minister Davutoğlu himself visited Kirkuk in August 2012, while Prime Minister Erdoğan pledged to dispatch Turkish troops to defend that city if it became necessary. ${ }^{65}$ Baghdad reacted to these moves by setting up new northern military headquarters, the Tigris Operations Command, charged with supervising operations in Kirkuk, Diyala, and Salah al-Din provinces. ${ }^{66}$ Sporadic clashes between Kurdish fighters and the Iraqi armed forces persisted throughout the winter of 2012-13. ${ }^{67}$

\section{Turkey Responds to Civil War in Syria}

Turkish officials grew increasingly alarmed over the turn to armed struggle undertaken by the Kurds of Syria and Iraq after the Kurdish community of Anatolia started to exhibit greater restiveness during the summer of 2011. Police responded to the revival of Kurdish political activism inside Turkey by unleashing the security forces and gendarmerie against demonstrators. ${ }^{68}$ When Kurdish fighters in Syria seized control of the towns of Ras al-'Ain and 'Afrin in July 2012, and a PKK flag was unfurled at Ras al-'Ain, Turkish commanders carried out a succession of large-scale military exercises along the border. At the same time, PKK militants based in northern Iraq severed the main highway at the border town of Semdinli, and were only dislodged by an intense air and armored operation. ${ }^{69}$ Ankara succeeded in persuading PKK leaders to

\footnotetext{
${ }^{64}$ Gunter, "Arab-Kurdish Relations,"1629-1630.

${ }^{65}$ Joost R. Hiltermann, "Revenge of the Kurds," Foreign Affairs 91 (November-December 2012): 16-22.

66 "Iraqi Kurdish Leader Says Region Will Defend Itself," Gulf Nerws, November 18, 2012, http://gulfnews.com/ news/region/iraq/iraqi-kurdish-leader-says-region-will-defend-itself-1.1106643.

${ }^{67}$ Liz Sly, "Rising Animosity between Iraqis and Kurds Raises Risk of War," Washington Post, November 21, 2012. ${ }^{68}$ Justin Vela, “Turkey: Iran Casts Shadow over New Kurdish Strategy," EurasiaNet.org, August 18, 2011, http:// www.eurasianet.org/node/64064.

${ }^{69}$ Roy Gutman, "Kurdish Offensive in Turkey has Indirect Syrian Backing," McClatchy News Service, August 16, 2012, http://www.mcclatchydc.com/2012/08/16/162515/kurdish-campaign-in-turkey-provides.html; Anthony Faiola, "Turkey Confronts a Resurgent Kurdish Threat," Washington Post, November 25, 2012, http:// www.washingtonpost.com/world/turkey-confronts-resurgent-kurdish-threat/2012/11/23/217b8a98-2da2-11e2a99d-5c4203af7b7a_gallery.html.
} 
accept a general ceasefire in March 2013, under whose terms PKK fighters agreed to leave Turkish territory. Scattered PKK formations crossed into northern Iraq in early May 2013, but refused to give up their weapons as they departed. ${ }^{70}$ The transfer took place over the strenuous objections of the government in Baghdad, which insisted that it "does not accept the entry of armed groups into [Iraqi] territory." ${ }^{11}$ Fighters who passed through northeastern Syria on their way to northern Iraq frequently skirmished with YPG guerrillas. ${ }^{72}$ And the Turkish government's ceasefire with the PKK did little to dampen festering Kurdish discontent inside Anatolia. ${ }^{73}$

Ankara's efforts to undercut Kurdish militants in southeastern Anatolia and northern Syria had the unintended consequence of disrupting Turkey's amicable relations with both Iran and Iraq. Rumors that Iranian troops had captured the PKK's senior military leader, but refused to turn him over to the Turkish authorities, circulated throughout the summer of 2011. A year later, Turkey's deputy prime minister complained publicly that unwavering Iranian support for the Ba'thi regime in Damascus had precipitated a round of bombings of police stations in southeastern Anatolia. Tehran responded by terminating the fifty-year-old arrangement whereby citizens from one country could enter the other without obtaining a visa. ${ }^{74}$ As relations between Iran and Azerbaijan soured during 2011-12, cooperation between Ankara and Baku blossomed apace. ${ }^{75}$

Baghdad reacted equally angrily when officials in Ankara advised Iraqi Prime Minister al-Maliki to do more to conciliate his country's discontented Sunni community, calling such advice an example of "unwarranted interference in the

\footnotetext{
${ }^{70}$ Dorian Jones, "Will PKK Ceasefire Change Turkey's Regional Role?" EurasiaNet.org, March 27, 2013, http://www.eurasianet.org/node/66751; "Kurdish Rebels Begin Withdrawal from Turkey," Reuters, May 8, 2013, http://www.reuters.com/article/2013/05/08/us-turkey-kurds-idUSBRE9470E420130508; Umut Uras, "Planned PKK Pullout Heats up Turkish Politics," Al Jazeera, May 8, 2013, http://www.aljazeera.com/indepth/ features/2013/05/201357182319457288.html.

71 “PKK Fighters Arrive in Iraq under Peace Deal," Al Jazeera, May 14, 2013, http://www.aljazeera.com/news/ europe/2013/05/20135147251149191.html.

${ }^{72}$ Bassim Francis, “Tensions Rise between Iraqi, Syrian-Kurdish Parties,” al-Hayah, May 22, 2013.

${ }^{73}$ Seyhmus Cakan, “Turkish Security Forces Fire on Protest in Southeast, One Dead," Reuters, June 28, 2013, http://www.reuters.com/article/2013/06/28/us-turkey-kurds-idUSBRE95R0CK20130628; Seyhmus Cakan, "Kurdish Protesters Clash with Turkish Security Forces," Reuters, June 30, 2013, http://www.reuters.com/ article/2013/06/30/us-turkey-kurds-idUSBRE95S0DE20130630.

${ }^{74}$ Farideh Farhi, "What to Make of the Latest Iranian-Turkish Row," LobeLog, August 13, 2012, http://www. lobelog.com/what-to-make-of-the-latest-iranian-turkish-row.

75 “Turkey, Azerbaijan Increase Cooperation,” Voice of America, March 20, 2012, http://www.voanews.com/ content/turkey-azerbaijan-diplomatic-and-economic-cooperation-increasing-143663786/179668.html.
} 
country's internal affairs." 76 To bring the point home, the Turkish embassy in Baghdad was struck by a rocket fired by unknown attackers. Undeterred, in February 2013, Prime Minister Erdoğan wondered aloud why Iraqi Sunnis did not set up a separate political space for themselves along the lines of the Kurdistan Regional Government: "If you speak of a transition to a federal system, why don't you consider the same system for Sulaimaniyyah, Kirkuk, or Mosul, too?"77 Criticisms of al-Maliki voiced by Turkish officials steadily took an overtly anti-Shi'i tone, stirring up greater animosity among the Iraqi authorities and populace alike, along with undisguised expressions of displeasure from Tehran.

\section{Iran Confronts Growing Security Threats}

Iran, meanwhile, confronted a marked resurgence of political mobilization among its Azeri minority. Large numbers of Azeris took to the streets of the northern Iranian metropolis of Tabriz and surrounding cities in August 2011, ostensibly to demand the restoration of the badly depleted waters of Lake Urmia. ${ }^{78}$ The demonstrators were met with tear gas and gunfire from riot police and security forces. There were reports that protesters routinely chanted pro-Turkey slogans, which had earlier been raised at matches involving Tabriz's Tractor Sazi Football Club. Spiraling tensions between the authorities and Azeri activists cast a pall over Tehran's already shaky relations with Baku, and opened the door to enhanced ties between the Islamic Republic and Armenia. ${ }^{79}$ Allegations that Iranian agents were planning to assassinate Israeli diplomats stationed in Azerbaijan further poisoned the atmosphere. ${ }^{80}$

In March 2013, a congress of Azeri nationalists met in Baku to discuss the prospects of independence for the Iranian provinces of West and East Azerbaijan. ${ }^{81}$

\footnotetext{
76 "Turkey Set to Benefit from Closer Iraqi Kurdish Ties," Oxford Analytica, January 30, 2012, https://www.oxan. com/display.aspx?ItemID=DB173433; Sevil Erkus, "Turkey Denies Role in Iraq's Political Crisis," Hurriyet Daily News, April 25, 2012, http://www.hurriyetdailynews.com/turkey-denies-role-in-iraqs-political-crisis.aspx?pageI $\mathrm{D}=238 \& n I D=19210 \& N e w s C a t I D=338$; Yigal Schleifer, "Growing Strains in Ankara's Relations with Baghdad," EurasiaNet.org, May 8, 2012, http://www.eurasianet.org/node/65375; Henri Barkey, "Turkey-Iraq Relations Deteriorate with Accusations of Sectarianism," Al-Monitor, February 8, 2013, http://www.al-monitor.com/pulse/ ar/contents/articles/originals/2012/al-monitor/turkey-iraq-ties-sour-brover-syr.html.

${ }_{77}$ Fehim Tastekin, “Turkey's Sunni Identity Test," Al-Monitor, June 21, 2013, http://www.al-monitor.com/pulse/ originals/2013/06/turkey-sunnism-sectarian-rhetoric.html.

${ }^{78}$ Emil Souleimanov, "Concerns over Urmia Lake Boosts Nationalism among Azerbaijanis in Iran," Central AsiaCaucasus Institute Analyst, October 5, 2011.

${ }^{79}$ Gayane Abrahamyan, "Armenia: Yerevan Wants to Open Up to Iran," EurasiaNet.org, January 26, 2012. http:// www.eurasianet.org/node/64910.

${ }^{80}$ Richard Weitz, "Iran's Self-Defeating Regional Strategy," Central Asia-Caucasus Institute Analyst, March 21, 2012.

${ }^{81}$ Mina Muradova, "New Tensions between Azerbaijan and Iran," Central Asia-Caucasus Institute Analyst, May $15,2013$.
} 
After Tehran issued a blistering condemnation of the gathering, Azerbaijan moved closer to Israel, as well as to Turkey. ${ }^{82}$ Armenia simultaneously opened its doors to Christians fleeing the civil war in Syria, many of whom were shunted onto lands that had long been claimed by Azerbaijan, which in turn rekindled long-standing territorial disputes. ${ }^{83}$ Ankara, meanwhile, took steps to cultivate diplomatic and economic relations with Kyrgyzstan, thereby outflanking the South Caucasus entirely. ${ }^{84}$ Closer connections between Ankara and Bishkek were buttressed by reports that Islamist militants based in Kyrgyzstan were undertaking the arduous journey to Syria to engage in jihad against the $\mathrm{Ba}$ 'thi regime in Damascus. ${ }^{85}$

\section{Syria Falls Out with HAMAS}

Lost in the shuffle was the strategic partnership between Syria and HAMAS, which had rested at the heart of the Middle Eastern regional security complex during the decade prior to the outbreak of the 2011 uprising. The authorities in Damascus exerted considerable pressure on HAMAS during the spring of 2011 to join Turkey, Iraq, and Iran in pledging unmitigated support for Syria's Ba'thi regime. But the leadership of HAMAS refused to take this fateful step, on the grounds that the movement had always adhered strictly to the "strategic principle not to intervene in the internal affairs of the $[\mathrm{Arab}]$ states." ${ }^{86}$ The Popular Front for the Liberation of Palestine-General Command, by contrast, sharply criticized HAMAS's refusal to back its long-time hosts, prompting HAMAS officials based in the Syrian capital to exit the country.

Alienated from its former allies in Damascus, HAMAS made overtures to the post-Mubarak leadership in Cairo. These signals were reciprocated by Egypt's Muslim Brothers, and in February 2012 the Egyptian authorities orchestrated a frosty reconciliation between HAMAS and the West Bank-based Palestinian Authority. Halting rapprochement between Egypt and HAMAS created profound misgivings in Israel, setting the stage for a series of Israeli air strikes against Palestinian forces in Gaza; these raids prompted HAMAS radicals to launch retaliatory rocket attacks

\footnotetext{
${ }^{82}$ Robert M. Cutler, "Facing Growing Iranian Threats, Azerbaijan Deepens Ties to Israel," Central Asia-Caucasus Institute Analyst, May 15, 2013; Shahin Abbasov, "Azerbaijan: Baku Faces Difficult Choice Between Turkey and Israel," EurasiaNet.org, September 26, 2011, http://www.eurasianet.org/node/64224.

${ }^{83}$ Marianna Grigoryan, “Armenia: An Uncertain 'Homecoming' for Syria's Diaspora,” EurasiaNet.org, July 31, 2012, http://www.eurasianet.org/node/65728; "Armenia: Syrian Refugees Resettling in Occupied Azerbaijani Territory," EurasiaNet.org, January 28, 2013, http://www.eurasianet.org/node/66461.

${ }^{84}$ Dmitry Shlapentokh, "Turkey and Kyrgyzstan Deepen Ties," Central Asia-Caucasus Institute Analyst, March 21, 2012.

${ }^{85}$ Altynai Myrzabekova and Lola Olimova, "Central Asian Recruits for Syrian Conflict," Institute for War and Peace Reporting, June 28, 2013, http://iwpr.net/report-news/central-asian-recruits-syrian-conflict.

${ }^{86}$ Ethan Bronner, “Tensions Rise as Hamas Refuses to Take Sides in Syria," New York Times, May 2, 2011, http:// www.nytimes.com/2011/05/03/world/middleeast/03hamas.html?_r=0.
} 
against Israeli territory. By early November 2012, the recurrent exchanges had become so severe that the IDF initiated a week-long military campaign to push Palestinian militants as far as possible away from the Gaza-Israel border. Iran immediately announced that it was supplying HAMAS with both financial aid and weaponry. The announcement marked the first public acknowledgement by Tehran that it had transferred sophisticated armaments to Gaza, including crucial components for intermediate-range Fajr-5 ballistic missiles.

Relations between Egypt and HAMAS deteriorated sharply after the July 2013 putsch in which the Egyptian armed forces ousted President Mohamed Morsi. Senior military commanders in Cairo suspected HAMAS of collaborating with the radical Islamist formations that exercised control over extensive areas of the Sinai Peninsula, and whose fighters responded to Morsi's removal by carrying out attacks against state installations adjacent to the border with Gaza. ${ }^{87}$ The Egyptian army launched a number of large-scale operations in northern Sinai during July and August 2013, followed by a more concerted offensive in early September. ${ }^{88}$ The rising frequency and intensity of these military initiatives not only alarmed Israel, which in turn deployed additional missile batteries along the border with Egypt, but also opened the door to a revival of the long-dormant strategic partnership between HAMAS and Iran. ${ }^{89}$

\section{Sectarianization of the Syrian Uprising and Prospects for Regional Contagion}

As the spring of 2013 turned into summer, the growing sectarianization of the Syrian civil war posed an increasingly severe threat that the conflict would spread to Turkey, Iraq, and Lebanon. In May 2013, an influential Turkish news magazine pointed out that so long as the Justice and Development Party-led government in Ankara "continues to resist a fair and peaceful solution to Alevi problems [inside Turkey], the Syrian quagmire could drown Turkey, pulling it [down] by its Alevi rein." 90 The danger of aggravated Sunni-Alevi polarization inside Turkey rose sharply after anti-government protests broke out across the country in June

\footnotetext{
${ }^{87}$ Adnan Abu Amer, "Hamas, Gaza's Armed Factions Struggle to Stay Out of Sinai Conflict," Al-Monitor, August 15, 2013, http://www.al-monitor.com/pulse/originals/2013/08/jihadists-gaza-sinai-egypt-israel-hamas.html.

88 Ahmed Eleiba, "Sinai Part III," al-Ahram Weekly, September 12-18, 2013, http://weekly.ahram.org.eg/ News/4066/17/Sinai-\%E2\%80\%94-Part-III.aspx; Shadia Nasralla, "Egypt Army Attacks Sinai Islamists as Militancy Spreads," Reuters, September 7, 2013, http://www.reuters.com/article/2013/09/07/us-egypt-protestsidUSBRE9860JT20130907.

${ }^{89}$ Adnan Abu Amer, “Will Hamas Re-Enter Iran's Orbit?” Al-Monitor, July 22, 2013, http://www.al-monitor. com/pulse/originals/2013/07/hamas-alliances-iran-egypt.html.

${ }^{90}$ Orhan Kemal Gengiz, "Syria’s War Impacts Turkish Alevis," Al-Monitor, May 29, 2013, http://www.al-monitor. com/pulse/originals/2013/05/turkey-alevi-problem-syria.html.
} 
2013. ${ }^{91}$ Furthermore, Ankara's largely futile attempts to contain Kurdish political activists in Syria by providing material and moral support to the Jabhat al-Nusrah li-Ahl al-Sham (Assistance Front for the People of Syria) proved more and more incendiary, as elements of the Front forged connections with radical Islamists based in northern Iraq.

Meanwhile, Kurdish forces consolidated their hold over cities and towns all across northern Syria. A new security unit attached to the Democratic Union Party, called Asayish, assumed a greater role in policing al-Qamishli and surrounding areas, sometimes in collusion with local remnants of the $\mathrm{Ba}$ thi regime. Agents of Asayish almost immediately started to root out and detain supporters of the Free Syrian Army, and by the late spring of 2013 the two sides were engaged in an all-out contest for command of the country's major oilfields. ${ }^{92}$ The struggle between the Popular Protection Units and Asayish on one side and elements of the FSA on the other provided an opportunity for radical Islamist militias, particularly the Jabhat al-Nusrah li-Ahl al-Sham (Assistance Front for the People of Syria), to expand operations in key oil-producing districts. As the Front and other radical Islamists gradually gained strength, isolated Christian communities in the northeastern marches set up an armed formation, the Sutoro, whose branches coordinated activities with the much betterarmed and more organized YPG. ${ }^{93}$

\section{Sectarian Conflict in Syria Threatens Turkey and Iraq}

Fighting among the Popular Protection Units, the Free Syrian Army, and radical Islamist formations in northern Syria prompted militants affiliated with the Kurdistan Workers' Party to abandon the tenuous ceasefire that it had implemented with the Turkish Republic. After several sporadic skirmishes, a cluster of more concerted attacks against police and gendarmerie stations shook districts surrounding Diyarbakir in early July 2013. ${ }^{94}$ The resurgence of PKK militance led officials in Ankara to reconsider their policy of backing Jabhat al-Nusrah li-Ahl al-Sham and other Islamist militias in Syria; the resulting diminution of outside support for Jabhat

\footnotetext{
${ }^{91}$ Justin Vela, “Turkey: Protests Reverberate in Anatolian Heartland," EurasiaNet.org,June 12, 2013, http://www. eurasianet.org/node/67110.

${ }_{92}$ Andrea Glioti, "Kurdish Group Gaining Autonomy in Northern Syria," Al-Monitor, May 7, 2013, http:// www.al-monitor.com/pulse/ar/contents/articles/opinion/2013/05/pyd-pkk-syria-kurdistan.html; Andrea Glioti, "Syrian Oil Becomes Fault Line in War," Al-Monitor, May 16, 2013, http://www.al-monitor.com/pulse/ originals/2013/05/syria-oil-kurds-pyd-eu.html.

${ }^{93}$ Andrea Glioti, “Syriac Christians, Kurds Boost Cooperation in Syria," Al-Monitor, June 20, 2013, http://www. al-monitor.com/pulse/originals/2013/06/syria-syriacs-assyrians-kurds-pyd.html.

${ }^{94}$ Reuters, July 4, 2013.
} 
al-Nusrah li-Ahl al-Sham enabled YPG fighters to expel the Front's cadres from Ras al-'Ain, 'Ain al-'Arab, and Tal Abyad at the end of July 2013.95

By early September 2013, the success of Kurdish militias in the struggle against radical Islamist formations, in conjunction with a resumption of large-scale, antigovernment protests in Turkey's southern and southeastern provinces, propelled Turkish Prime Minister Erdoğan to announce a package of reforms that included allowing the Kurdish language to be used in private schools and electoral campaigns, and exempting Kurdish children from the ritual morning pledge: "How happy is one who calls himself a Turk." ${ }^{96}$ Such measures did little, however, to placate Anatolia's disaffected Alevis, who not only chafed at the preferential treatment that was being accorded Sunni refugees from Syria but also resented the marked disruption in intersectarian amity caused by the arrival of rising numbers of displaced Syrian 'Alawites. ${ }^{97}$

Prospects for near-term stability looked even bleaker to Syria's east. A pitched battle between Syrian troops and Free Syrian Army units at Ya'arbiyyah on the Iraqi border in March 2013 eventuated in the resurgence of the radical Iraqi movement that called itself al-Dawlah al-Islamiyyah fi al-'Iraq (the Islamic State of Iraq or ISI). The leadership of the ISI proclaimed that Prime Minister al-Maliki was engaged in "firm co-operation" with Syrian President al-Assad. This allegation appeared to be verified by the Iraqi army's willingness to protect a contingent of Syrian soldiers that escaped into Iraqi territory during the course of the battle, and to escort the soldiers back to Syria. ${ }^{98}$ Over the next few weeks, FSA units were dislodged from several major border crossings by fighters of Jabhat al-Nusrah li-Ahl al-Sham, facilitating combined operations between the Front and the ISI.

In early April 2013, the two formations announced that they had amalgamated, and intended to work together in future as al-Dawlah al-Islamiyyah fi al-'Iraq wa alSham (the Islamic State of Iraq and the Levant, or ISIL). Despite subsequent orders from the head of al-Qa'ida to reverse the merger, the leader of the ISIL, known by the nom de guerre Abu Bakr al-Baghdadi, insisted that the amalgamation was permanent, and that ISIL fighters would start to strike Shi'a, 'Alawites, and "the Party of Satan" (the group's code name for Hizbullah) by whatever means possible. ${ }^{99}$

\footnotetext{
${ }^{95}$ Husnu Mahalli, "Back to the Turkish Quagmire in Syrian Kurdistan,” al-Akbbar English, July 22, 2013, http:// english.al-akhbar.com/node/16494.

${ }_{96}$ Agence France Presse, October 1, 2013.

97 Constanze Letsch, “Turkey: Syria Conflict Heightens Alevi Tension,” EurasiaNet.org, October 11, 2013, http://www.eurasianet.org/node/67623.

${ }_{98}$ BBC, March 11, 2013.

99 Adam Schreck, “Al-Qaida’s Iraq Head Defies Boss over Syria,” Associated Press, June 15, 2013.
} 
Throughout the late spring and early summer of 2013, rivalry escalated between the Islamic State of Iraq and the Levant and other radical Islamist militias in northeastern Syria, including components of Jabhat al-Nusrah li-Ahl al-Sham (Assistance Front for the People of Syria), that had refused to acquiesce in the merger with the Islamic State of Iraq. The competition prompted ISIL commanders to engage in armed combat against other Islamist groupings, in particular Kata'ib Ahrar al-Sham (Battalions of the Free of Syria). Local Free Syrian Army units around al-Raqqah then formed the so-called Eleventh Division to defend the city against the ISIL, Kata'ib Ahrar al-Sham, and elements of the Jabhat al-Nusrah li-Ahl al-Sham that were firmly entrenched at the nearby Tabqah Dam on the Euphrates. In mid-August 2013, ISIL fighters drove the Eleventh Division out of al-Raqqah, and a month later pushed FSA units out of the northern town of al-Bab as well. The ISIL then attacked the FSA's Liwa' Allahu Akbar (God is Greatest Brigade) at Dair al-Zur and clashed with the FSA garrison at Abu Kamal on the Iraqi border.

On September 18, 2013, ISIL cadres seized control of A'zaz from a local militia loosely affiliated with the FSA; the well-armed Unity Brigade (Liwa' al-Tawhid) of Aleppo subsequently joined the battle for the adjacent Bab al-Salamah border crossing, which raged for three days until a shaky ceasefire took hold. In a desperate bid to block the rise of the ISIL, half a dozen Islamist formations, including Jabhat al-Nusrah li-Ahl al-Sham, Liwa' al-Tawhid, and Suqur al-Sham, then agreed to coordinate their tactical operations. The alliance was subsequently augmented by Kata'ib Ahrar al-Sham (Battalions of the Free of Syria), Harakat Fajr al-Islam (Dawn of Islam Movement), and Liwa' al-Haqq (Truth Brigade), based at Homs. ${ }^{100}$ Even acting more or less in concert, this disparate collection of militias proved incapable of dislodging the ISIL from the positions that it captured in August and September 2013. Kurdish Popular Protection Units, by contrast, managed to gain ground in the struggle against the ISIL, and took control of extensive areas of al-Hasakah province, as well as Ya'arabiyyah on the Iraqi border, at the end of October 2013.

Ankara therefore confronted both an expanding radical Islamist current and an increasingly firmly entrenched Kurdish national movement along its southern border in the fall of 2013. Turkish military commanders launched a limited artillery barrage against ISIL positions outside A'zaz as a cautionary signal to the former, while officials in the foreign ministry took steps to improve relations with Baghdad

100 Washington Post, September 25, 2013. 
as a means of exerting pressure on the latter. ${ }^{101}$ Turkish Foreign Minister Davutoğlu traveled to the Iraqi capital on November 10, 2013, and made a point to visit the Shi' $i$ pilgrimage cities of Najaf and Karbala and to meet with both Ayatollah 'Ali al-Sistani and Muqtada al-Sadr. As Semih Idiz notes, "Davutoglu's visit represents a new phase of outreach to the Shiites and indicates that Ankara is trying to pull itself back onto neutral territory after having openly favored the Sunnis in Syria." ${ }^{102}$ Kurdish nationalists in Syria reacted to Turkey's overtures to Iraq by upping the ante: on November 11, 2013, leaders of the Democratic Union Party announced plans to set up an interim transitional administration based at al-Qamishli. The transitional body would oversee the drafting of a provisional constitution and organize elections for a regional polity consisting of three cantons: al-Hasakah, 'Afrin, and 'Ain al'Arab (Kobani). ${ }^{103}$ The project was welcomed by the PYD's primary political rival in the Syrian Kurdish community, the People's Council of West Kurdistan, but it was rejected out of hand by the KDP-led Kurdish National Council, as well as by several smaller Kurdish political parties. ${ }^{104}$

\section{Turkey Advances into Iraq and Beyond}

Turkish officials attempted to derail potential regional backing for an autonomous Kurdish entity in Syria by strengthening relations with the Kurdistan Regional Government. In early November 2013, KRG Prime Minister Nechirvan Barzani arrived in Ankara to initial a package of agreements that provided for the construction of a massive oil and gas pipeline network that would connect petroleum-producing areas of northern Iraq with a number of Turkish ports. ${ }^{105}$ To implement the agreements, the Turkish authorities set up a new enterprise, the Turkish Energy Company, to operate in partnership with ExxonMobil, one of the primary foreign hydrocarbons companies active in the KRG. Ankara agreed to remit payment for all oil and gas shipped through the new network directly to the KRG, rather than to the central treasury in Baghdad. Turkish Prime Minister Erdoğan then invited KRG President

\footnotetext{
${ }^{101}$ Milliyet, October 9, 2013 and October 31, 2013.

${ }^{102}$ Semih Idiz, "Turkey Charts New Course in Iraq," Al-Monitor, November 15, 2013, http://www.al-monitor. com/pulse/originals/2013/11/turkey-middle-east-fresh-approach.html.

${ }^{103}$ Wladimir van Wilgenburg, "Syrian Kurdish Party Declares Transitional Government," Al-Monitor, November 12, 2013, http://www.al-monitor.com/pulse/originals/2013/11/syria-kurds-government-plan-wilgenburg.html.

${ }^{104}$ Wladimir van Wilgenburg, "Kurds Divided over Syrian Autonomy," Al-Monitor, November 19, 2013, http:// www.al-monitor.com/pulse/originals/2013/11/syrian-autonomy-divides-kurds.html.

${ }^{105}$ Humeyra Pamuk and Orhan Coskun, "Turkey, Iraq Clinch Major Energy Pipeline Deals," Reuters, November 6, 2013, http://www.reuters.com/article/2013/11/06/us-turkey-iraq-kurdistan-idUSBRE9A50HR20131106.
} 
Mas'ud Barzani to meet him in Diyarbakir. ${ }^{106}$ These initiatives sparked a burst of outrage in Baghdad, which Turkish officials did their best to assuage. ${ }^{107}$

At the same time, Turkey took steps to augment economic ties to Azerbaijan, Afghanistan, and Pakistan. In mid-October 2013, the authorities in Kabul granted the Turkish Petroleum Company rights to explore and develop several prospective oilfields inside Afghanistan. Ankara's growing presence in the countries along its northeastern perimeter irritated Tehran, which demonstrated its disapproval of such initiatives by obstructing the routine flow of goods along vital transportation routes. ${ }^{108}$ More important, Turkey's turn toward Afghanistan and Pakistan coincided with Israeli efforts to cultivate links with Turkmenistan, which further stoked Tehran's fears that Iran was becoming encircled by actual and potential adversaries. ${ }^{109}$

\section{Iraq Turns in on Itself}

For Iraq, the revival of the Islamic State of Iraq movement and its transformation into the Islamic State of Iraq and the Levant accompanied a sharp escalation in the frequency and severity of attacks against Shi'i targets all across the country. ISIL activities elicited renewed activism on the part of Jaish al-Mukhtar (Mukhtar Army), a militant Iraqi Shi' $i$ formation that staunchly opposed Iraqi Prime Minister alMaliki and his allies. At the same time, the mobilization of Kurdish militias inside Syria inspired Iraqi Kurds outside the purview of the KRG to take up arms, most remarkably under the auspices of the shadowy Rijal al-Tariqah al-Naqshbandiyyah (Army of the Men of the Naqshbandi Order), which was headed by a senior figure in the former Ba'thi regime in Baghdad, 'Tzzat Ibrahim al-Duri. Armed clashes between disparate groups of Sunni militants and the state security services erupted around Musil on a regular basis throughout the spring of 2013.

Skirmishes among rival sectarian militias exacerbated struggles between al-Maliki's government and an assortment of political challengers. Supporters of Muqtada al-

\footnotetext{
106 Mehmet Yegin, "Barzani and Erdogan in Diyarbakir," EurasiaReview, November 25, 2013, http://www. eurasiareview.com/25112013-barzani-erdogan-diyarbakir-oped/

${ }^{107}$ Fehim Tastekin, “Turkey Returns to Balance in Baghdad, KRG Ties," Al-Monitor, November 14, 2013, http:// www.al-monitor.com/pulse/originals/2013/11/turkey-juggles-baghdad-erbil.html; Humeyra Pamuk, "Turkey Stands by Kurdish Oil Deal, Seeks to Appease Baghdad," Reuters, December 2, 2013, http://www.reuters.com/ article/2013/12/02/us-iraq-turkey-idUSBRE9B108M20131202; Tim Arango and Clifford Krauss, "Kurds' Oil Deals with Turkey Raise Fears of Fissures in Iraq," New York Times, December 2, 2013, http://www.nytimes. com/2013/12/03/world/middleeast/kurds-oil-deals-with-turkey-raise-fears-of-fissures-in-iraq.html

108 Zaman, October 13, 2013.

109 Murat Sadykov, "Turkmenistan: Israeli PM Seeks to Bolster Relations on Iran's Border," EurasiaNet.org, October 1, 2013, http://www.eurasianet.org/node/67568. See Manochehr Dorraj and Nader Entessar, Iran's Northern Exposure: Foreign Policy Challenges in Eurasia, CIRS Occasional Paper no. 13 (Doha: Center for International and Regional Studies, Georgetown University School of Foreign Service in Qatar, 2013).
} 
Sadr took to the streets in January 2013 to demand the prime minister's immediate resignation and new parliamentary elections. At the same time, anti-government demonstrations erupted across the northwestern provinces of al-Anbar, Nineveh, and Salah al-Din. ${ }^{110}$ Growing popular unrest led tribal leaders in al-Anbar province to set up armed units to protect the protesters from attacks by the Iraqi armed forces and security agencies; these units were reported to have attracted large numbers of ISIL fighters into their ranks. ${ }^{111}$ Stunned by the emergence of such Sunni militias, Muqtada al-Sadr, in late May 2013, issued "a final warning to the government to assume its duty of protecting the people," and demanded that Prime Minister al-Maliki order the dissolution of all armed Islamist formations, including Asa'ib Ahl al-Haqq (Bands of the People of Truth). ${ }^{112}$ This demand received the enthusiastic endorsement of Sunni civil rights activists in al-Anbar province, thereby laying the foundation for a potential inter-sectarian challenge to the prime minister and his partners.

Provincial elections in the spring of 2013 resulted in a dramatic loss of influence for the governing I'tilaf Dawlat al-Qanun (State of Law Coalition). Allies of Prime Minister al-Maliki ended up winning only half the number of provincial governorships that they had won in 2009, and lost control of the crucial governorship of Baghdad province. ${ }^{113}$ Sensing that his authority was waning, al-Maliki quietly encouraged the proliferation of armed Shi'i formations, as a counterweight to rival political parties. ${ }^{114}$ An upsurge in bombings around Baghdad in mid-August 2013 prompted the militias of the Kurdistan Democratic Party and Patriotic Union of Kurdistan to move into the capital to secure government offices. ${ }^{115}$ At the same time, escalating friction between the supporters of Muqtada al-Sadr and Asa'ib Ahl al-Haqq persuaded al-Sadr to retreat from active participation in politics. ${ }^{116}$ Splits inside Iraq's Shi'i community were accompanied by accelerated fragmentation among Sunnis, particularly between allies of the influential preacher Sheikh 'Abd al-Malik al-Sa'di and proponents of an

${ }^{110}$ Al-Hayah, January 2, 2013.

111 The Guardian, May 21, 2013.

112 Ali Abel Sadah, "Sadr Gives Maliki 'Final Warning," Al-Monitor, May 29, 2013, http://www.al-monitor. com/pulse/originals/2013/05/sadr-maliki-iraq-warning.html; "Iraqi Militias Make Comeback Amid Surging Sectarian Violence," Radio Free Europe/Radio Liberty,June 20, 2013, http:/www.rferl.org/content/iraq-militiassectarian-violence/25023363.html.

${ }^{113}$ Laith Hammoudi, “Iraqi Premier's Party Losing Grip on Regions," Institute for War and Peace Reporting, July 3, 2013, http://iwpr.net/report-news/iraqi-premier\%E2\%80\%99s-party-losing-grip-regions.

114 Ali Mamouri, “The Rise of 'Cleric Militias' in Iraq," Al-Monitor, July 23, 2013, http://www.al-monitor.com/ pulse/originals/2013/07/shiite-cleric-militias-iraq-fears.html

115 Ali Abel Sadah, “Iraqi Kurdish Forces Help Defend Baghdad," Al-Monitor, August 16, 2013, http://www.almonitor.com/pulse/originals/2013/08/military-meeting-baghdad-erbil-iraq.html.

${ }^{116}$ Frud Bezhan, "Reports of Muqtada al-Sadr's Political Demise Greatly Exaggerated," Radio Free Europe/Radio Liberty, August 19, 2013, http://www.rferl.org/content/iraq-muqtada-al-sadr-/25079761.html. 
autonomous Sunni federal region that would encompass al-Anbar, Nineveh, and Salah al-Din provinces. ${ }^{117}$

Under these circumstances, officials in Baghdad resorted to large-scale military operations in an attempt to maintain order in the northwestern marches adjacent to the Syrian border. ${ }^{118}$ Such operations primarily targeted Islamist militants who were alleged to be affiliated with Jabhat al-Nusrah li-Ahl al-Sham (Assistance Front for the People of Syria) and al-Dawlah al-Islamiyyah fi al-'Iraq wa al-Sham (Islamic State of Iraq and the Levant), whose cadres had established footholds in the northern Iraqi cities of Musil and Nineveh. ${ }^{119}$ But they also struck at contingents of Asa'ib Ahl alHaqq (Bands of the People of Truth) based in Diyala province. ${ }^{120}$ The offensives led radical Islamist militias to retaliate against a broad range of military and government installations. ${ }^{121}$ An attack on the town of 'Ana in al-Anbar province in late September 2013 involved tactics that closely resembled ones practiced by radical Islamist fighters in northern Syria, while militant Iraqi preachers increasingly adopted rhetoric that mirrored the pronouncements of such Syrian Sunni firebrands as Sheikh 'Adnan al'Ar'ur. ${ }^{122}$ In a desperate bid to contain the spiralling violence, Prime Minister al-Maliki embarked on a quixotic campaign to revive the so-called al-Sahwah (Awakening) councils that United States military commanders had sponsored during the campaign to combat Islamist militants in 2007-08. ${ }^{123}$

\section{Sectarian Conflict Flares in Lebanon}

Syria's increasingly sectarian civil war created parallel instability inside Lebanon. Sheikh Ahmad al-Assir, a radical Sunni preacher based in southern Lebanon who was known for his intense and outspoken antipathy toward Hizbullah, gained considerable

\footnotetext{
117 Mushreq Abbas, "Iraqi Sheikh Faces Divisions within Sunni Community," Al-Monitor, September 10, 2013, http://www.al-monitor.com/pulse/originals/2013/09/iraqi-sunnis-struggle-to-find-authority.html.

118 Al-Hayah, September 17, 2013.

${ }^{119}$ Harith Hasan, "al-Qaeda Sinks Roots in Mosul," Al-Monitor, October 24, 2013, http://www.al-monitor.com/ pulse/originals/2013/10/al-qaeda-mosul-iraq-sunnis-minorities.html.

${ }^{120}$ Al-Hayah, September 18, 2013.

${ }^{121}$ Al-Safir, September 18, 2013.

122 Associated Press, September 24, 2013; Mushreq Abbas, "al-Qaeda Sets Sights on Iraq's Anbar Province," Al-Monitor, October 25, 2013, http://www.al-monitor.com/pulse/originals/2013/10/anbar-valuable-for-alqaeda.html; Ali Abel Sadah, "Iraqi Sunni Leader Accused of Inciting Violence against Shiites," Al-Monitor, October 1, 2013, http://www.al-monitor.com/pulse/originals/2013/10/iraq-sunni-leader-incitement-shiites. html; Washington Post, December 7, 2013; Suadad al-Salhy, "Al Qaeda Tightens Grip on Western Iraq in Bid for Islamic State," Reuters, December 11, 2013, http://www.reuters.com/article/2013/12/11/us-iraq-violence-alqaeda-idUSBRE9BA0O820131211.

${ }^{123}$ Al-Hayah, October 14, 2013; “Al Qaeda Strikes Fear into Iraq's Government-Backed Sunni Militia,” Reuters, October 18, 2013, http://www.reuters.com/article/2013/10/18/us-iraq-sahwa-idUSBRE99H0DH20131018; alHayah, October 28, 2013; Harith Hasan, "Al-Qaeda Sinks Roots in Mosul," Al-Monitor, October 24, 2013, http:// www.al-monitor.com/pulse/originals/2013/10/al-qaeda-mosul-iraq-sunnis-minorities.html.
} 
notoriety during the spring of 2012 for his enthusiastic expressions of support for the Islamist formations that were engaged in armed struggle against Syria's Ba'thi regime. ${ }^{124}$ Militant followers of al-Assir clashed with cadres of the leftist al-Tanzim al-Sha'bi al-Nasiri (Popular Nasirist Organization) in the southern Lebanese city of Sa'idah in August 2012; three months later, skirmishes broke out between Assirists and Hizbullah, in the wake of which al-Assir announced plans to set up an organized military formation. Although he quickly abandoned the militia project, al-Assir's fulminations against Hizbullah elicited growing admiration from disadvantaged Sunnis and discontented Shi' is throughout South Lebanon. Islamist and Bathi opponents of al-Assir's movement formed Tajammu' al-Qawmi al-Islami (Islamic National Gathering) in an effort to dampen rising sectarian tensions and promote interdenominational coexistence. ${ }^{125}$

Inter-sectarian fighting erupted in the northern Lebanese city of Tripoli at the end of 2012. Different neighborhoods organized armed bands and gradually fell under the control of rival commanders (amirs), whose activities posed a direct challenge to the police and security services. ${ }^{126}$ Local grudges assumed a distinctly sectarian character as 2013 opened, with residents of the predominantly 'Alawi district of Jabal Muhsin finding themselves subjected to frequent attacks at the hands of Sunni thugs. Such assaults accompanied sporadic attacks by supporters of the Syrian opposition against supply convoys that traversed Lebanese roads on their way to Damascus; the attacks on occasion elicited retaliatory strikes by the Syrian armed forces against Lebanese territory. ${ }^{127}$

In mid-April 2013, al-Assir announced that his supporters had set up Liwa' alMuqawamah al-Hurra (Free Resistance Brigade) in order to carry out armed struggle (jihad) against Syria's Ba'thi regime. ${ }^{128}$ The first contingents of this militia crossed the border in late May to help radical Syrian Islamists defend the strategic Syrian town of al-Qusair; in response, Hizbullah deployed units that fought alongside Syrian troops in the battle to dislodge the militants. The struggle between Liwa' al-Muqawamah al-Ahrar and Hizbullah set the stage for a resumption of clashes between Lebanese

\footnotetext{
${ }^{124}$ Radwan Mortada, "Al-Assir: A New Guardian of 'Sunni Interests' in Lebanon,” al-Akhbar English, March 2, 2012, http://english.al-akhbar.com/node/4759; As'ad Abu Khalil, "Lebanon's Ahmad al-Assir Phenomenon," alAkbbar English, June 24, 2013, http://english.al-akhbar.com/node/16226.

${ }_{125}$ Amal Khalil, "Shaikh al-Assir Targets Saida’s Shi'i Mosque," al-Akhbar English, April 18, 2013, http://english. al-akhbar.com/node/15568.

${ }^{126}$ Al-Safir, January 4, 2013.

127 “Syrian Jet Flies into Lebanon, Fires Missile," Reuters, April 3, 2013, http://www.reuters.com/ article/2013/04/03/us-syria-crisis-lebanon-jet-idUSBRE93209Z20130403.

${ }^{128}$ Amal Khalil, "Shaikh al-Assir Declares Arrival of His Mujahidin in Syria," al-Akbbar English, April 27, 2013, http://english.al-akhbar.com/node/15646.
} 
Islamist and Lebanese Ba'thi fighters in Tripoli at the end of May 2013. ${ }^{129}$ A month later, armed Assirists attacked an army checkpoint in Sa'idah, igniting a bloody confrontation between Liwa' al-Muqawamah al-Ahrar and elements of the Lebanese armed forces. ${ }^{130}$ Meanwhile, fighting erupted between Shi'a and Sunnis in the region around the Lebanese town of Arsal on the border with Syria. ${ }^{131}$

Simultaneous challenges from the Assirists and Sunni militants in Tripoli and Arsal, combined with Hizbullah's increasing direct participation in the Syrian war, sparked a resurgence of criticism of Secretary General Nasrallah's leadership inside Hizbullah, particularly by radicals loyal to Subhi al-Tufaili. In early July 2013, al-Tufaili charged that Hizbullah's intervention in Syria had been undertaken on direct orders from Iran, and that this action threatened to "open the door wide to a war between Sunnis and Shi 'is" all across Lebanon. ${ }^{132}$ Friction between moderates and radicals inside Hizbullah heightened after a massive car bomb exploded near the party's security headquarters in the Bir al-'Abid district of southern Beirut. ${ }^{133}$ Secretary General Nasrallah quickly took steps to reassure his supporters, but in a public address in early August 2013 went a step too far and referred to himself as a "Shi' i" figure, thereby alienating many of his non-Shi ${ }^{i} i$ allies. ${ }^{134}$

Shortly after this speech, an even larger car bomb detonated in southern Beirut, which was reported to have elicited popular celebrations in Sunni neighborhoods of Tripoli. ${ }^{135}$ More bombs exploded at key points in Tripoli a week later, followed by reports that the attacks in southern Beirut had been carried out by fighters affiliated with Liwa' al-Islam (Islam Brigade), a Syrian opposition militia based in the Qalamun district, just across the border from Arsal. ${ }^{136}$ At the same time, the Homs-based Liwa' al-Haqq (Truth Brigade) was reported to have established operational links to radical Islamist fighters around Tripoli, prompting the former commander of the Lebanese Internal Security Force to organize a collection of that city's armed bands into a combined formation, which called itself Ahrar Tarabulus (Free of Tripoli). ${ }^{137}$

\footnotetext{
${ }^{129}$ Haytham Mouzahem, "Tripoli a Reflection of Syria’s Sectarian War," Al-Monitor, May 25, 2013, http://www. al-monitor.com/pulse/originals/2013/05/lebanon-tripoli-syria-crisis.html.

${ }^{130}$ New York Times, June 24, 2013.

${ }^{131}$ Sarah E1 Deeb, “Killing of 4 Shiites in Lebanon Deepens Tension,” Associated Press, June 16, 2013.

132 al-Sharq al-Awsat, July 3, 2013.

133 “Bombing Wounds 53 in Hezbollah Stronghold," Associated Press, July 10, 2013.

134 al-Safir, August 5, 2013.

135 Jean Aziz, "Blast in Beirut Sparks Fears of 'Iraqization' of Lebanon," Al-Monitor, August 15, 2013, http://www. al-monitor.com/pulse/originals/2013/08/major-bomb-blast-beirut-southern-suburbs-lebanon.html.

136 al-Safir, October 18, 2013.

137 “Former Police Chief Establishes Militia in Tripoli," al-Akbbar English, October 29, 2013, http://english.alakhbar.com/node/17447.
} 
On November 19, 2013, two car bombs exploded outside the Iranian embassy compound in the southern Beirut district of Bir Hasan. Observers immediately pointed out similarities between that operation and ones carried out by al-Qa'ida affiliates in Iraq, most notably the fact that the attacks involved suicide bombers. ${ }^{138}$ Iranian officials did their best to deflect blame for the attack onto Israel, even though a Lebanese grouping loosely tied to al-Qa'ida, Alwiyat 'Abdullah 'Azzam ('Abdullah 'Azzam Brigades), claimed responsibility and described the operation as a retaliatory strike in response to Hizbullah's ongoing involvement in Syria. ${ }^{139}$ Later investigation indicated that the attackers enjoyed intimate connections to the Assirist movement, and the Lebanese armed forces launched a campaign to round up and arrest known Assirist activists at the end of November 2013. ${ }^{140}$ Hizbullah then warned that the actions of al-Assir's supporters were pushing the country toward "an exact replica of the Iraq situation." ${ }^{141}$

Meanwhile, violence flared once again between Sunnis and 'Alawites in Tripoli, and banners of Jabhat al-Nusrah li-Ahl al-Sham (Assistance Front for the People of Syria) and al-Dawlah al-Islamiyyah fi al-'Iraq wa al-Sham (Islamic State of Iraq and the Levant) began to appear in the predominantly Sunni district of Bab al-Tabbanah. ${ }^{142}$ At the same time, Sunni militants rooted in the impoverished countryside east of Tripoli infiltrated into the city to fight alongside their urban brethren. ${ }^{143}$ During a television interview on December 3, 2013, Hizbullah's Secretary General Nasrallah charged for the first time that Saudi Arabia was providing material and financial support for radical Sunni militias operating in Lebanon. ${ }^{144}$ The interview took place in the wake of a summit meeting of the Gulf Cooperation Council (GCC), during the course of which the six GCC member-

\footnotetext{
138 "Iran Embassy Bombing: Repeat of Iraqi Model in Lebanon," Al-Monitor, November 19, 2013, http://www. al-monitor.com/pulse/originals/2013/11/beirut-iran-embassy-bombing-iraq.html.

${ }_{139}$ Dominic Evans, "Beirut Blast: Jolt from Past and Omen of Dark Future," Reuters, November 20, 2013, http:// www.reuters.com/article/2013/11/20/us-syria-crisis-lebanon-analysis-idUSBRE9AJ1AA20131120; Maria AbiHabib, “Beirut Attack Marks Militant Resurgence," Wall Street Journal, November 21, 2013, http://online.wsj. com/news/articles/SB10001424052702304607104579210151841138592.

${ }^{140}$ Amal Khalil, "Embassy Suicide Bombers are Graduates of the Assir School," al-Akhbar English, November 26, 2013, http://english.al-akhbar.com/node/17714.

141 al-Rai al-'Amm, November 26, 2013.

${ }^{142}$ Nazih Siddiq, “Six Killed in Clashes in Lebanon's Tripoli,” Reuters, November 30, 2013, http://www.reuters. com/article/2013/11/30/us-lebanon-tripoli-idUSBRE9AT03K20131130; Nazih Siddiq, "Syria-Fuelled Violence Kills Four in Lebanon's Tripoli,” Reuters, December 1, 2013, http://www.reuters.com/article/2013/12/01/uslebanon-tripoli-idUSBRE9B005120131201; Mohamed Nazzal, "Tripoli Shoots Itself in the Foot," al-Akbbar English, December 2, 2013, http://english.al-akhbar.com/node/17777.

${ }^{143}$ Nasser Chararah, "Lebanon's Tripoli Microcosm for Syria Conflict," Al-Monitor, December 12, 2013, http:// www.al-monitor.com/pulse/originals/2013/12/lebanon-tripoli-microcosm-syria-war.html.

${ }^{144}$ Nasser Chararah, "Hezbollah Escalates Rhetoric against Riyadh," Al-Monitor, December 10, 2013, http:// www.al-monitor.com/pulse/originals/2013/12/hezbollah-escalates-rhetoric-saudi-arabia.html.
} 
states had imposed tighter sanctions on all organizations linked to Hizbullah. Two days after the broadcast aired, Hizbullah's head of military operations, Hasan alLaqis, was assassinated outside his home in the eastern Lebanese town of Baalbek; two previously unknown Islamist groups claimed responsibility, but informed observers intimated that Saudi security operatives stood behind the killing. ${ }^{145}$

\section{Conclusion}

Prior to the popular uprisings that erupted across the Arab world in the winter of 2010-11, the Middle Eastern regional security complex consisted of a relatively compact set of core actors-Syria, Israel, Hizbullah, and HAMAS-whose internal struggles generated overlapping external policies that had a direct impact on the security interests of Turkey, Iraq, Iran, and Lebanon. Strategic rivalries among these eight actors steadily enlarged the Middle Eastern RSC so that it came to incorporate several states in the South and North Caucasus, yet generated a comparatively low level of interstate conflict.

In the wake of the uprisings, and in particular following the transformation of the popular revolt in Syria into a full-blown civil war, the Middle Eastern RSC has expanded once more, with Turkey, Iraq, Iran, and Lebanon becoming more deeply entangled than before, and a number of states in the Caucasus, Central Eurasia, and South Asia feeling the impact of the Syrian conflict. More important, the regional security complex has become much more volatile, as escalating inter-sectarian antagonism inside Syria has added fuel to sectarian-related tensions smoldering in neighboring countries. Increasingly brutal and indiscriminate fighting among radical Islamist formations and Kurdish militants on one hand and the Jabhat al-Nusrah liAhl al-Sham (Assistance Front for the People of Syria) and al-Dawlah al-Islamiyyah fi al-'Iraq wa al-Sham (Islamic State of Iraq and the Levant) on the other, along with ongoing struggles between independent Islamist militias and largely autonomous components of the Free Syrian Army, poses unprecedented threats to Turkey, Iraq, and Lebanon. These external threats have exacerbated burgeoning internal tensions in each of these three countries, and in Iran as well, which have impelled their respective leaderships to undertake foreign policies that put one another's security interests in severe jeopardy. Given these overlapping dynamics, the potential for interstate conflict in the Middle Eastern regional security complex has risen sharply, and can be expected to continue to accelerate so long as the Syrian uprising rages out of control.

145 “Key Hezbollah Chief Killed," Santa Rosa Press Democrat, December 5, 2013. 



\section{BIBLIOGRAPHY}

Ababsa, Myriam. "The Shi'i Mausoleums of Raqqa: Iranian Proselytism and Local Significations.” In Demystifying Syria, edited by Fred H. Lawson, 85-104. London: Saqi Books, 2009.

Abadi,Jacob. "Israel's Quest for Normalization with Azerbaijan and the Muslim States of Central Asia." Journal of Third World Studies 19, no. 2 (Fall 2002): 63-88.

Abbas, Mushreq. "al-Qaeda Sets Sights on Iraq's Anbar Province." Al-Monitor, October 25, 2013. http://www.al-monitor.com/pulse/originals/2013/10/ anbar-valuable-for-al-qaeda.html.

—. "Iraqi Sheikh Faces Divisions within Sunni Community." Al-Monitor, September 10, 2013. http://www.al-monitor.com/pulse/originals/2013/09/ iraqi-sunnis-struggle-to-find-authority.html.

Abbasov, Shahin. “Azerbaijan: Baku Faces Difficult Choice between Turkey and Israel.” EurasiaNet.org, September 26, 2011. http://www.eurasianet.org/node/64224.

Abi-Habib, Maria. "Beirut Attack Marks Militant Resurgence.” Wall Street Journal, November 21, 2013. http://online.wsj.com/news/articles/SB1000142405270 2304607104579210151841138592.

Abrahamyan, Gayane. “Armenia: Yerevan Wants to Open Up to Iran.” EurasiaNet.org, January 26, 2012. http://www.eurasianet.org/node/64910.

Abu Amer, Adnan. "Will Hamas Re-Enter Iran’s Orbit?” Al-Monitor, July 22, 2013. http://www.al-monitor.com/pulse/originals/2013/07/hamas-alliances-iranegypt.html.

- "Hamas, Gaza's Armed Factions Struggle to Stay Out of Sinai Conflict." Al-Monitor, August 15, 2013. http://www.al-monitor.com/pulse/ originals/2013/08/jihadists-gaza-sinai-egypt-israel-hamas.html.

Abu Khalil, As'ad. "Lebanon's Ahmad al-Assir Phenomenon." al-Akbbar English, June 24, 2013. http://english.al-akhbar.com/node/16226.

Ahmed, Asso. "Iranian Troops Building Fort in Iraq." Los Angeles Times, June 8, 2010. http://articles.latimes.com/2010/jun/08/world/la-fg-iraq-iranincursion-20100609. 
al-Akbbar English. "Former Police Chief Establishes Militia in Tripoli." October 29, 2013. http://english.al-akhbar.com/node/17447.

al-Hakkar, Firas. “The Mysterious Fall of Raqqa, Syria's Kandahar." al-Akbbar English, November 8, 2013. http://english.al-akhbar.com/node/17550.

Al Jazeera. "Turkey Presses Ahead with PKK Offensive." October 20, 2011. http:// www.aljazeera.com/news/middleeast/2011/10/201110221411345914.html.

Al Jazeera. "PKK Fighters Arrive in Iraq under Peace Deal." May 14, 2013. http:// www.aljazeera.com/news/europe/2013/05/20135147251149191.html.

Al-Monitor. "Iran Embassy Bombing: Repeat of Iraqi Model in Lebanon." November 19, 2013. http://www.al-monitor.com/pulse/originals/2013/11/beirut-iranembassy-bombing-iraq.html.

al-Salhy, Suadad. "Al Qaeda Tightens Grip on Western Iraq in Bid for Islamic State.” Reuters, December 11, 2013. http://www.reuters.com/article/2013/12/11/usiraq-violence-al-qaeda-idUSBRE9BA0O820131211.

Arango, Tim, and Clifford Krauss. "Kurds' Oil Deals with Turkey Raise Fears of Fissures in Iraq." New York Times, December 2, 2013. http://www.nytimes. com/2013/12/03/world/middleeast/kurds-oil-deals-with-turkey-raise-fearsof-fissures-in-iraq.html.

Arango, Tim, and Michael R. Gordon. "Sectarian Strains Pit Some Iraqis against their own Leaders." New York Times, March 19, 2013. http://www.nytimes. com/2013/03/20/world/middleeast/fading-hopes-of-unity-in-iraq-assectarian-tensions-rise.html.

Associated Press. "Bombing Wounds 53 in Hezbollah Stronghold.”July 10, 2013.

Aziz, Jean. "Blast in Beirut Sparks Fears of 'Iraqization' of Lebanon." Al-Monitor, August 15, 2013. http://www.al-monitor.com/pulse/originals/2013/08/ major-bomb-blast-beirut-southern-suburbs-lebanon.html.

Bank, André. Turkey and the Arab Revolt: Rise or Decline in Regional Politics? GIGA Focus 4. German Institute of Global and Area Studies. Berlin, 2011. http://www.gigahamburg.de/en/system/files/publications/gf_international_1104.pdf. 
Barkey, Henri J. “Turkey and Iraq: The Making of a Partnership.” Turkish Studies 12, no. 4 (December 2011): 663-674.

. "Turkey-Iraq Relations Deteriorate with Accusations of Sectarianism." AlMonitor, February 8, 2013. http://www.al-monitor.com/pulse/ar/contents/ articles/originals/2012/al-monitor/turkey-iraq-ties-sour-brover-syr.html.

Bengio, Ofra. "The 'Kurdish Spring' in Turkey and its Impact on Turkish Foreign Relations in the Middle East." Turkish Studies 12, no. 4 (December 2011): 619-632. doi: 10.1080/14683849.2011.622509.

Bezhan, Frud. "Reports of Muqtada al-Sadr's Political Demise Greatly Exaggerated." Radio Free Europe/Radio Liberty, August 19, 2013. http://www.rferl.org/ content/iraq-muqtada-al-sadr-/25079761.html.

Bishku, Michael B. "The Relations of the Central Asian Republics of Kazakhstan and Uzbekistan with Israel." Middle Eastern Studies 48, no. 6 (November 2012): 927-940.

Blank, Stephen. "Nagorno-Karabakh: A Disaster in the Making?” Central Asia-Caucasus Institute Analyst. Bi-Weekly Briefing 11, no 25 (December 23, 2009): 3-5. http://www.silkroadstudies.org/new/docs/publications/091223analyst.pdf.

Bourtman, Ilya. “Israel and Azerbaijan's Furtive Embrace.” Middle East Quarterly 13, no. 3 (Summer 2006): 47-57.

Bronner, Ethan. “Tensions Rise as Hamas Refuses to Take Sides in Syria.” New York Times, May 2, 2011. http://www.nytimes.com/2011/05/03/world/ middleeast/03hamas.html?_r=0.

Cakan, Seyhmus. "Turkish Security Forces Fire on Protest in Southeast, One Dead.” Reuters, June 28, 2013. http://www.reuters.com/article/2013/06/28/usturkey-kurds-idUSBRE95R0CK20130628.

- "Kurdish Protesters Clash with Turkish Security Forces." Reuters, June 30, 2013. http://www.reuters.com/article/2013/06/30/us-turkey-kurdsidUSBRE95S0DE20130630.

Chararah, Nasser. "Hezbollah Escalates Rhetoric against Riyadh." Al-Monitor, December 10, 2013. http://www.al-monitor.com/pulse/originals/2013/12/ hezbollah-escalates-rhetoric-saudi-arabia.html. 
- "Lebanon's Tripoli Microcosm for Syria Conflict." Al-Monitor, December 12, 2013. http://www.al-monitor.com/pulse/originals/2013/12/lebanon-tripolimicrocosm-syria-war.html.

Cutler, Robert M. "Facing Growing Iranian Threats, Azerbaijan Deepens Ties to Israel.” Central Asia-Caucasus Institute Analyst, May 15, 2013. http://www. cacianalyst.org/publications/analytical-articles/item/12730-facing-growingiranian-ties-azerbaijan-deepens-ties-to-israel.html.

Dombey, Daniel, and Funja Guler, “Turkey Hits Kurdish Targets in Iraq," Financial Times, August 19, 2011.

Dorraj, Manochehr, and Nader Entessar. Iran's Northern Exposure: Foreign Policy Challenges in Eurasia. Occasional Paper no. 13. Doha: Center for International and Regional Studies, Georgetown University School of Foreign Service in Qatar, 2013.

El Deeb, Sarah. "Killing of 4 Shiites in Lebanon Deepens Tension.” Associated Press, June 16, 2013.

Eleiba, Ahmed. "Sinai Part III.” al-Ahram Weekly, September 12-18, 2013. http:// weekly.ahram.org.eg/News/4066/17/Sinai-\%E2\%80\%94-Part-III.aspx

Eligür, Banu. "Crisis in Turkish-Israeli Relations (December 2008-June 2011): From Partnership to Enmity.” Middle Eastern Studies 48, no. 3 (May 2012): 429-459. doi: 10.1080/00263206.2012.662893.

Erkus, Sevil. “Turkey Denies Role in Iraq’s Political Crisis.” Hurriyet Daily News, April 25, 2012. http://www.hurriyetdailynews.com/turkey-denies-role-in-iraqspolitical-crisis.aspx?pageID=238\&nID $=19210 \& N$ News $C$ atID $=338$.

EurasiaNet.Org. "Armenia: Syrian Refugees Resettling in Occupied Azerbaijani Territory.” January 28, 2013. http://www.eurasianet.org/node/66461.

Evans, Dominic. "Beirut Blast: Jolt from Past and Omen of Dark Future." Reuters, November 20, 2013. http:/www.reuters.com/article/2013/11/20/us-syriacrisis-lebanon-analysis-idUSBRE9AJ1AA20131120.

Fadel, Leila. "Clashes in Iraq's North Underscore Fierce Political Rivalry." Washington Post, March 5, 2010. http://www.washingtonpost.com/wp-dyn/content/ article/2010/03/04/AR2010030405153.html. 
Faiola, Anthony. "Turkey Confronts a Resurgent Kurdish Threat." Washington Post, November 25, 2012. http://www.washingtonpost.com/world/turkeyconfronts-resurgent-kurdish-threat/2012/11/23/217b8a98-2da2-11e2-a99d5c4203af7b7a_gallery.html.

Farhi, Farideh. "What to Make of the Latest Iranian-Turkish Row." LobeLog, August 13, 2012. http://www.lobelog.com/what-to-make-of-the-latest-iranianturkish-row/.

Francis, Bassim. "Tensions Rise between Iraqi, Syrian-Kurdish Parties.” al-Hayah, May 22, 2013.

Gengiz, Orhan Kemal. "Syria’s War Impacts Turkish Alevis." Al-Monitor, May 29, 2013. http://www.al-monitor.com/pulse/originals/2013/05/turkey-aleviproblem-syria.html.

Glioti, Andrea. "Kurdish Group Gaining Autonomy in Northern Syria." Al-Monitor, May 7, 2013. http://www.al-monitor.com/pulse/ar/contents/articles/ opinion/2013/05/pyd-pkk-syria-kurdistan.html.

__. "Syrian Oil Becomes Fault Line in War." Al-Monitor, May 16, 2013. http:// www.al-monitor.com/pulse/originals/2013/05/syria-oil-kurds-pyd-eu.html.

. "Syriac Christians, Kurds Boost Cooperation in Syria." Al-Monitor, June 20, 2013. http://www.al-monitor.com/pulse/originals/2013/06/syria-syriacsassyrians-kurds-pyd.html.

Grigoryan, Marianna. “Armenia: An Uncertain 'Homecoming' for Syria’s Diaspora.” EurasiaNet.org, July 31, 2012. http://www.eurasianet.org/node/65728.

Gulf Nerws. "Iraqi Kurdish Leader Says Region Will Defend Itself." November 18, 2012. http://gulfnews.com/news/region/iraq/iraqi-kurdish-leader-saysregion-will-defend-itself-1.1106643.

Gunter, Michael M. "Arab-Kurdish Relations and the Future of Iraq." Third World Quarterly 32, no. 9 (October 2011): 1623-1635. doi: 10.1080/01436597.2011.618649.

Gutman, Roy. "Kurdish Offensive in Turkey has Indirect Syrian Backing." McClatchy News Service, August 16, 2012. http:/www.mcclatchydc. com/2012/08/16/162515/kurdish-campaign-in-turkey-provides.html. 
Hammoudi, Laith. "Iraqi Premier's Party Losing Grip on Regions." Institute for War and Peace Reporting, July 3, 2013. http://iwpr.net/report-news/iraqipremier\%E2\%80\%99s-party-losing-grip-regions.

Hamzawy, Amr. "Adventurism versus Submission.” al-Ahram Weekly, July 27-August 2, 2006. http://weekly.ahram.org.eg/2006/805/op121.htm.

Hasan, Harith. "Al-Qaeda Sinks Roots in Mosul.” Al-Monitor, October 24, 2013. http://www.al-monitor.com/pulse/originals/2013/10/al-qaeda-mosul-iraqsunnis-minorities.html.

Hiltermann, Joost R. "Revenge of the Kurds." Foreign Affairs 91, no. 6 (NovemberDecember 2012): 16-22.

Idiz, Semih. “Turkey Charts New Course in Iraq.” Al-Monitor, November 15, 2013. http://www.al-monitor.com/pulse/originals/2013/11/turkey-middle-eastfresh-approach.html.

Inbar, Efraim. The Deterioration in Israeli-Turkish Relations and its International Ramifications. Mideast Security Policy Studies no. 89. Ramat Gan: BeginSadat Center for Strategic Studies, Bar-Ilan University, February 2011. http:// www.biu.ac.il/Besa/MSPS89.pdf.

International Crisis Group. Syria's Kurds: A Struggle Within a Struggle. Middle East Report no. 136, January 22, 2013, 33. http://www.crisisgroup.org/en/regions/ middle-east-north-africa/egypt-syria-lebanon/syria/136-syrias-kurds-astruggle-within-a-struggle.aspx.

Ismailzade, Fariz. "Azerbaijani-Iranian Relations Endangered after Russian Publication." Central Asia-Caucasus Institute Analyst, June 4, 2003. http://old. cacianalyst.org/?q=node/1208.

Jenkins, Gareth H. Occasional Allies, Enduring Rivals: Turkey's Relations with Iran. Washington, D. C.: Central Asia-Caucasus Institute and Silk Road Studies Program, May 2012. http://www.silkroadstudies.org/new/docs/ silkroadpapers/1205Jenkins.pdf.

Jones, Dorian. “Will PKK Ceasefire Change Turkey's Regional Role?” EurasiaNet.org, March 27, 2013. http://www.eurasianet.org/node/66751. 
Kane, Sean. The Coming Turkish-Iranian Competition in Iraq. Special Report no. 276. Washington, D. C.: United States Institute of Peace, June 2011. http://www. usip.org/sites/default/files/Turkish_Iranian_Competition.pdf.

Kerr, Malcolm H. The Arab Cold War: Gamal Abd al-Nasir and His Rivals, 1958-1970. $3^{\text {rd }}$ ed. London: Oxford University Press.

Khachatrian, Haroutiun. "Resumed Deadlock in the South Caucasus at the Anniversary of the Karabakh Cease-Fire." Central Asia-Caucasus Institute Analyst. BiWeekly Briefing 12, no. 9 (May 13, 2010): 9-11. http://www.silkroadstudies. org/new/docs/publications/100512analyst.pdf.

Khalil, Amal. "Embassy Suicide Bombers are Graduates of the Assir School." al-Akbbar English, November 26, 2013. http://english.al-akhbar.com/node/17714.

. "Shaikh al-Assir Declares Arrival of His Mujahidin in Syria." al-Akbbar, April 27, 2013. http://english.al-akhbar.com/node/15646

- "Shaikh al-Assir Targets Saida's Shi'i Mosque." al-Akbbar, April 18, 2013. http://english.al-akhbar.com/node/15568.

Khoury, Nabeel A. “The Arab Cold War Revisited.” Middle East Policy 20, no. 2 (Summer 2013): 73-87.

Lawson, Fred H. "New Twists, More Intricate Configurations: The Changing IsraelPalestinian Regional Security Complex." Perspectives on Global Development and Technology 6, nos. 1-3 (2007): 345-362.

ed. "The Beginning of a Beautiful Friendship: Syrian-Turkish Relations since 1998." In Demystifying Syria, 180-205. London: Saqi Books, 2009.

. Global Security Watch Syria. Santa Barbara, CA: Praeger, 2013.

Leenders, Reinoud. “Regional Conflict Formations': Is the Middle East Next?” Third World Quarterly 28, no. 5 (May 2007): 959-982.

_. "Strong States in a Troubled Region: Anatomies of a Middle Eastern Regional Conflict Formation.” Comparative Social Research 27, no. 1 (2010): 171-195. 
Letsch, Constanze. "Turkey: Syria Conflict Heightens Alevi Tension.” EurasiaNet.org, October 11, 2013. http://www.eurasianet.org/node/67623.

Mahalli, Husnu. "Back to the Turkish Quagmire in Syrian Kurdistan." al-Akbbar English, July 22, 2013. http://english.al-akhbar.com/node/16494.

Mamedov, Eldar. "How Deep are Azerbaijan-Israel Relations?" EurasiaNet.org, January 18, 2013. http://www.eurasianet.org/node/66431.

Mamouri, Ali. "The Rise of 'Cleric Militias' in Iraq." Al-Monitor, July 23, 2013. http:// www.al-monitor.com/pulse/originals/2013/07/shiite-cleric-militias-iraqfears.html.

Mortada, Radwan. "Al-Assir: A New Guardian of 'Sunni Interests' in Lebanon.” alAkbbar English, March 2, 2012. http://english.al-akhbar.com/node/4759.

Mouzahem, Haytham. "Tripoli a Reflection of Syria’s Sectarian War." Al-Monitor, May 25, 2013. http://www.al-monitor.com/pulse/originals/2013/05/lebanontripoli-syria-crisis.html.

Muradova, Mina. "New Tensions between Azerbaijan and Iran." Central Asia-Caucasus Institute Analyst, May 15, 2013. http://www.cacianalyst.org/publications/ field-reports/item/12733-new-tensions-between-azerbaijan-and-iran.html.

Muradyan, Vahagn. "Armenia and Georgia in the Context of the Turkish-Armenian Rapprochement." Central Asia-Caucasus Institute Analyst, Bi-Weekly Briefing 12, no. 5 (March 17, 2010): 6-8. http://www.silkroadstudies.org/new/docs/ publications/100317analyst.pdf.

Muzalevsky, Roman. "The Armenia-Turkey Protocols." Central Asia-Caucasus Institute Analyst, November 11, 2009. http://www.cacianalyst.org/publications/ analytical-articles/item/11942-analytical-articles-caci-analyst-2009-11-11art-11942.html.

Myrzabekova, Altynai, and Lola Olimova. "Central Asian Recruits for Syrian Conflict." Institute for War and Peace Reporting, June 28, 2013. http://iwpr.net/reportnews/central-asian-recruits-syrian-conflict.

Nakkash, Aziz. The Alawite Dilemma in Homs. Berlin: Ebert Stiftung, March 2013. 
Nasralla, Shadia. "Egypt Army Attacks Sinai Islamists as Militancy Spreads.” Reuters, 7 September 2013. http://www.reuters.com/article/2013/09/07/us-egyptprotests-idUSBRE9860JT20130907.

Nazzal, Mohamed. "Tripoli Shoots Itself in the Foot." al-Akbbar English, December 2, 2013. http://english.al-akhbar.com/node/17777.

Oxford Analytica. “Turkey Set to Benefit from Closer Iraqi Kurdish Ties.” January 30, 2012. https://www.oxan.com/display.aspx?ItemID=DB173433.

Pamuk, Humeyra. “Turkey Stands by Kurdish Oil Deal, Seeks to Appease Baghdad.” Reuters, December 2, 2013. http://www.reuters.com/article/2013/12/02/usiraq-turkey-idUSBRE9B108M20131202.

Pamuk, Humeyra, and Orhan Coskun. "Turkey, Iraq Clinch Major Energy Pipeline Deals." Reuters, November 6, 2013. http://www.reuters.com/ article/2013/11/06/us-turkey-iraq-kurdistan-idUSBRE9A50HR20131106.

Parker, Ned. "Iraq Violence Sparks Fear of a Sunni Revolt." Los Angeles Times, April 24, 2013. http://articles.latimes.com/2013/apr/23/world/la-fg-iraqprotests-20130424.

Perrier, Guillaume. "Iraqi-Based Kurdish Guerrillas Do Battle with Tehran.” The Guardian, August 31, 2010. http://www.theguardian.com/world/2010/ aug/31/iran-kurdish-guerrillas-battle.

Radio Free Europe/Radio Liberty. "Iraqi Militias Make Comeback Amid Surging Sectarian Violence.” June 20, 2013. http://www.rferl.org/content/iraqmilitias-sectarian-violence/25023363.html.

Reinhart, Tanya. The Road Map to Nowhere. London: Verso, 2006.

Reuters. "Al Qaeda Strikes Fear into Iraq's Government-Backed Sunni Militia." October 18, 2013. http://www.reuters.com/article/2013/10/18/us-iraqsahwa-idUSBRE99H0DH20131018.

. “Iran Says Kills 30 Kurd Rebels in New Border Push.” September 3, 2011. http://www.reuters.com/article/2011/09/03/us-iran-kurds-operationidUSTRE7821G120110903.

—_. "Kurdish Rebels Begin Withdrawal from Turkey." May 8, 2013. http://www. reuters.com/article/2013/05/08/us-turkey-kurds-idUSBRE9470E420130508. 
—. "Syrian Jet Flies into Lebanon, Fires Missile." April 3, 2013. http:// www.reuters.com/article/2013/04/03/us-syria-crisis-lebanon-jetidUSBRE93209Z20130403.

Ryan, Curtis. "The New Arab Cold War and the Struggle for Syria." Middle East Report no. 262 (Spring 2012): 28-31. http://www.merip.org/mer/mer262/new-arabcold-war-struggle-syria.

Sadah, Ali Abel. "Sadr Gives Maliki 'Final Warning.” Al-Monitor, May 29, 2013. http:/www.al-monitor.com/pulse/originals/2013/05/sadr-maliki-iraqwarning.html.

. "Iraqi Sunni Leader Accused of Inciting Violence against Shiites." Al-Monitor, October 1, 2013. http://www.al-monitor.com/pulse/originals/2013/10/iraqsunni-leader-incitement-shiites.html.

—_. "Iraqi Kurdish Forces Help Defend Baghdad." Al-Monitor, August 16, 2013. http:/www.al-monitor.com/pulse/originals/2013/08/military-meetingbaghdad-erbil-iraq.html.

Sadykov,Murat. "Turkmenistan: Israeli PM Seeks to Bolster Relations on Iran's Border." EurasiaNet.org, October 1, 2013. http://www.eurasianet.org/node/67568.

Salloukh, Bassel. "Syria and Lebanon: A Brotherhood Transformed." Middle East Report no. 236 (Fall 2005): 14-21. http://www.merip.org/mer/mer236/syrialebanon-brotherhood-transformed.

Santa Rosa Press Democrat. “Key Hezbollah Chief Killed.” December 5, 2013.

Schleifer, Yigal. "Turkey and Iran: Amidst the Smiles, A Rivalry Intensifies." EurasiaNet.org, February 23, 2012. http://www.eurasianet.org/node/65040.

. “Growing Strains in Ankara's Relations with Baghdad.” EurasiaNet.org, May 8, 2012. http://www.eurasianet.org/node/65375.

Schreck, Adam. “Al-Qaida's Iraq Head Defies Boss over Syria.” Associated Press, June 15,2013

Shlapentokh, Dmitry. "Kadyrov's Contacts with Israel and the Jihadist Threat." Central Asia-Caucasus Institute Analyst, Bi-Weekly Briefing 12, no. 9 (May 13, 2010): 6-8. http://www.silkroadstudies.org/new/docs/ publications/100512analyst.pdf. 
- "Turkey and Kyrgyzstan Deepen Ties." Central Asia-Caucasus Institute Analyst, March 21, 2012.

Siddiq, Nazih. "Six Killed in Clashes in Lebanon's Tripoli." Reuters, November 30, 2013. http://www.reuters.com/article/2013/11/30/us-lebanon-tripoliidUSBRE9AT03K20131130

_. "Syria-Fuelled Violence Kills Four in Lebanon's Tripoli." Reuters, December 1,2013

Sly, Liz. "Rising Animosity between Iraqis and Kurds Raises Risk of War." Washington Post, November 21, 2012.

Souleimanov, Emil. "Concerns over Urmia Lake Boosts Nationalism among Azerbaijanis in Iran." Central Asia-Caucasus Institute Analyst, October 5, 2011. http://old.cacianalyst.org/?q=node/5637.

Tanir, Ilhan, Wladimir van Wilgenburg, and Omar Hossino. Unity or PYD Power Play? Syrian Kurdish Dynamics after the Erbil Agreement. London: The Henry Jackson Society Papers.July 2012.http://henryjacksonsociety.org/wp-content/ uploads/2012/10/HJS_Unity-or-PYD-Power-Play_-Report.pdf.

Tastekin, Fehim. “Dreaming of 'Zion' on the 'Alawis Behalf.” Radikal, 27 May 2013.

—_. “Turkey's Sunni Identity Test.” Al-Monitor, June 21, 2013. http://www.almonitor.com/pulse/originals/2013/06/turkey-sunnism-sectarian-rhetoric. html.

_. "Turkey Returns to Balance in Baghdad, KRG Ties." Al-Monitor, November 14, 2013. http://www.al-monitor.com/pulse/originals/2013/11/turkeyjuggles-baghdad-erbil.html.

Tol, Gonul. “The Kurdish Dimension of Turkey's Syria Policy.” Foreign Policy, April 10, 2012. http://mideastafrica.foreignpolicy.com/posts/2012/04/10/the_kurdish_ issue_in_turkey_s_syria_policy.

Uras, Umut. “Planned PKK Pullout Heats up Turkish Politics.” Al Jazeera, May 8, 2013. http://www.aljazeera.com/indepth/features/2013/05/201357182319457288.html.

van Wilgenburg, Wladimir. "Syrian Kurdish Party Declares Transitional Government.” Al-Monitor, November 12, 2013. http://www.al-monitor.com/pulse/ originals/2013/11/syria-kurds-government-plan-wilgenburg.html. 
—_. "Kurds Divided over Syrian Autonomy." Al-Monitor, November 19, 2013. http://www.al-monitor.com/pulse/originals/2013/11/syrian-autonomydivides-kurds.html.

Valbjørn, Morten, and André Bank. "Signs of a New Arab Cold War." Middle East Report no. 242 (Spring 2007): 6-11.

—. "The New Arab Cold War: Rediscovering the Arab Dimension of Middle East Regional Politics." Review of International Studies 38, no. 1 (January 2012): 3-24.

Vela, Justin. “Turkey: Iran Casts Shadow over New Kurdish Strategy.” EurasiaNet.org, August 18, 2011. http://www.eurasianet.org/node/64064.

_ . "Turkey: Protests Reverberate in Anatolian Heartland.” EurasiaNet.org, June 12, 2013. http://www.eurasianet.org/node/67110.

Voice of America. “Turkey, Azerbaijan Increase Cooperation.” March 20, 2012. http:// www.voanews.com/content/turkey-azerbaijan-diplomatic-and-economiccooperation-increasing-143663786/179668.html.

Weitz, Richard. "Iran's Self-Defeating Regional Strategy." Central Asia-Caucasus Institute Analyst. March 21, 2012. http://old.cacianalyst.org/?q=node/5738.

Wimmen, Heiko, and Muzehher Selcuk. "The Rise of Syria's Kurds." Sada, Carnegie Endowment for International Peace, February 5, 2013. http:// carnegieendowment.org/sada/2013/02/05/rise-of-syria-s-kurds/fcsw.

Wood, Josh. "In Syria, Kurds Carve out Territory of Their Own." Al-Monitor, October 4, 2012. http://www.al-monitor.com/pulse/originals/2012/al-monitor/syriakurds-derek-protest.html.

Yegin, Mehmet. “Barzani and Erdogan in Diyarbakir." Eurasia Review. November 25, 2013. http:/www.eurasiareview.com/25112013-barzani-erdogan-diyarbakiroped.

Zisser, Eyal. "Hizballah and Israel: Strategic Threat on the Northern Border." Israel Affairs 12, no. 1 (January 2006): 86-106. doi: 10.1080/13537120500381893. 


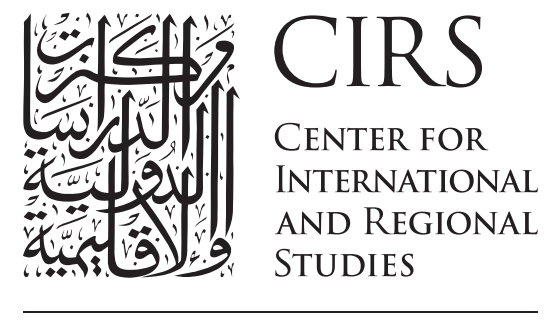

GEORGETOWN UNIVERSITY SCHOOL OF FOREIGN SERVICE IN QATAR 


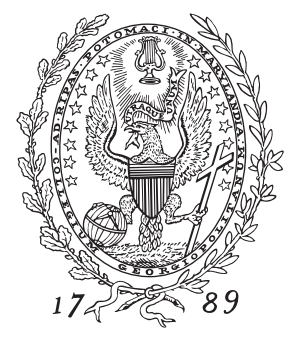

\section{GEORGETOWX CUNIVERSITY}

\section{School of Foreign Service in Qatar}

Center for International and Regional Studies

P.O. Box 23689

Doha, Qatar

http://cirs.georgetown.edu

Tel +974 44578400

Fax +974 44578401 


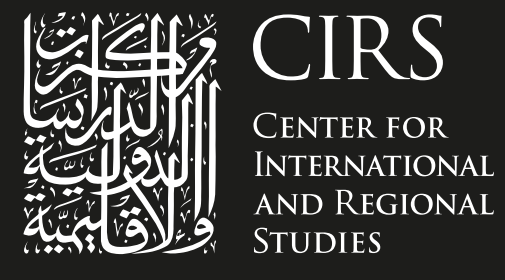

GEORGETOWN UNIVERSITY SCHOOL OF FOREIGN SERVICE IN QATAR 